\title{
Effect of Projected Land Use and Climate Change on Water Quality of Old Woman Creek Watershed, Ohio
}

\author{
Israel A. Olaoye ${ }^{1, *}$, Remegio B. Confesor, Jr. ${ }^{2}$ and Joseph D. Ortiz ${ }^{3(1)}$ \\ 1 Texas Institute for Applied Environmental Research (TIAER), Tarleton State University, \\ Stephenville, TX 76401, USA \\ 2 Norwegian Institute of Bioeconomy Research, 1430 Ås, Norway; remegio.confesor@nibio.no \\ 3 Department of Geology, Kent State University, Kent, OH 44240, USA; jortiz@kent.edu \\ * Correspondence: olaoye@tarleton.edu
}

Citation: Olaoye, I.A.; Confesor, R.B. Jr.; Ortiz, J.D. Effect of Projected Land Use and Climate Change on Water Quality of Old Woman Creek Watershed, Ohio. Hydrology 2021, 8, 62. https://doi.org/10.3390/ hydrology 8020062

Academic Editor: Minxue $\mathrm{He}$

Received: 31 January 2021

Accepted: 30 March 2021

Published: 4 April 2021

Publisher's Note: MDPI stays neutral with regard to jurisdictional claims in published maps and institutional affiliations.

Copyright: (c) 2021 by the authors. Licensee MDPI, Basel, Switzerland. This article is an open access article distributed under the terms and conditions of the Creative Commons Attribution (CC BY) license (https:// creativecommons.org/licenses/by/ $4.0 /)$.

\begin{abstract}
The separate and synergistic effects of land use and climate change on water quality variables in Old Woman Creek (OWC) watershed were evaluated using a hydrological model set up in Soil and Water Assessment Tool (SWAT) for the OWC watershed. Model calibration was done using a multi-objective evolutionary algorithm and pareto optimization. The ParameterElevation Regressions on Independent Slopes Model (PRISM) climate data and the 20 different Global Circulation Models (GCMs) developed by the Coupled Model Intercomparison Project Phase five (CMIP5) were used. Validation was done using the streamflow data from USGS gaging station and water quality data from the water quality lab, Heidelberg University. The simulation was divided into two land use scenarios: Scenario 1 for constant land use and Scenario 2 where land use was varied. Both land use simulations were run in four time periods to account for climate change: historical (1985-2014), current to near future (2018-2045), mid-century (2046-2075), and late-century (2076-2100) climate windows. For the historical period, the average of all the simulations made from the 20 different CMIP5 GCMs shows good agreement with the PRISM results for flow and the water quality variables of interest with smaller inter-model variability compared to PRISM results. For the other three climate windows, the results of Scenario 1 show an increase in flow and eight water quality variables (sediment (total suspended sediment), organic nitrogen, organic phosphorus (particulate $\mathrm{p}$ ), mineral phosphorus (soluble reactive $\mathrm{p}$ ), chlorophyll a, carbonaceous biochemical oxygen demand (CBOD), dissolved oxygen, total nitrogen) across the climate windows but a slight decrease in one water quality variable, mineral phosphorus in the mid-century. The results of Scenario 2 show a greater increase in flow, and the eight water quality variables across the climate windows show a relatively larger decrease in one water quality variable (mineral phosphorus). The projected land use change has little impact compared to the projected climate change on OWC watershed in the 21st century.
\end{abstract}

Keywords: SWAT; multi-objective; pareto optimization; PRISM; CMIP5

\section{Introduction}

In previous centuries, the influence of land use/land cover (LULC) changes on water were not recognized. It is now generally acceptable that the analysis of historical effects of LULC can produce knowledge about the present, and inferences about the future [1,2]. LULC are indisputable causes of changes in environmental conditions throughout the world and promote losses in biodiversity and deforestation [3]. The effect of LULC on streamflow has been described in previous studies [4,5]. Gebremicael et al. [6] noted that the conversion of a large area of vegetation into agricultural land in the Blue Nile Basin between 1970 and 2010 increased the wet season flow and decreased the dry season flow. In the upper mid-western United States, the previous land use change reported was the conversion of forest to agricultural land, and the recent land use change was 
urbanization [7,8]. Niyogi et al. [9] has established that urban growth can significantly affect climate and hydrological balance. Population growth, proximity to major urban centers, and migration pattern can influence urban growth $[10,11]$.

Urban areas have paved or impervious surfaces resulting in reduced infiltration and increased surface runoff into the water bodies [12]. The combined effect of increasing agricultural fertilizers and chemical use and increasing urbanization can severely impact the water quality of a watershed. The synergistic effect of LULC changes and climate changes could further warm the land surface [13]. LULC change and climate change contribute to each other after a long period of time [14,15].

This work attempts to address how the projected 21st century land use and climate change would impact the water quality of OWC watershed. Thus, the goal was to evaluate the separate and the synergistic effects of the projected LULC and climate change in the 21st century on streamflow and nutrient transport in OWC watershed using 20 different Global Circulation Models (GCMs) from the Coupled Model Intercomparison Project Phase five (CMIP5) model ensemble. This involves finding out how close the SWAT simulated flow and water quality variables from the $20 \mathrm{GCMs}$ are with the simulated values from the Parameter-Elevation Regressions on Independent Slopes Model (PRISM) historical climate data (1985-2014). Then, using the predicted LULC and the corresponding GCMs, the flow and water quality variables were simulated for future climate windows up to 2100 . The first hypothesis was, if SWAT simulation results from the 20 GCMs are consistent, within error of SWAT simulations run with PRISM data for the historical period, then the 20 GCMs can be used to run simulations for future scenarios. The second hypothesis was that the future projected land use change $(-3.6 \%$ agriculture and $+2.4 \%$ in urban) from the present should have an insignificant impact on water quality variables in OWC relative to the projected changes in temperature $(+47 \%)$ and precipitation $(+13 \%)$ across the century. The water quality variables of main focus in this study are sediment (total suspended sediment), organic nitrogen, organic phosphorus (particulate $\mathrm{p}$ ), mineral phosphorus (soluble reactive p), chlorophyll a, carbonaceous biochemical oxygen demand (CBOD), dissolved oxygen, total nitrogen, and total phosphorus.

\section{Materials and Methods}

\subsection{Modeling Scenarios}

The analysis was carried out in two scenarios: Scenario 1 where land use is constant and climate is varied, and Scenario 2 where both land use and climate are varied accordingly in four climate windows: W1-historical (1985-2014), W2-current to near future (2018-2045), W3-mid-century (2046-2075), and W4-late-century (2076-2100). For the historical climate window, simulation was set up for 1982-2014, but a warm up period of 3 years was used; hence, the simulation results obtained was from 1985-2014. The following steps were taken to achieve the overall objective:

1. PRISM climate data (1985-2014): simulating flow and water quality variables at annual time scale for the historical climate window (1985-2014) using PRISM climate data and the actual land use data.

2. CMIP5 GCMs simulation (1985-2014): simulating flow and water quality variables at annual time scale for the historical climate window (1985-2014) using 20 different GCMs climate models and the actual land use data.

3. Comparing the simulations made with PRISM with those made with the 20 different GCMs from CMIP5 for the historical climate window (1985-2014).

4. Scenario 1 GCMs simulations (2018-2100): simulating flow and water quality variables at annual time scale for the current to near future (2018-2045), mid-century (2046-2075), and late-century (2076-2100) climate windows using 20 GCMs from CMIP5 and constant land use.

5. Scenario 2 GCMs simulations (2018-2100): simulating flow and water quality variables at annual time scale for current to near future (2018-2045), mid-century (2046-2075), 
and late-century (2076-2100) climate windows using 20 GCMs from CMIP5 and the corresponding projected land use data for the climate windows.

6. Comparing simulation results for Scenario 1 and Scenario 2.

\subsection{Site Description}

The OWC is located on the south-central shore of Lake Erie in northern Ohio. It drains approximately $69 \mathrm{~km}^{2}$ of a watershed mainly used for agriculture [16] (Figure 1) [17]. OWC was selected as a suitable site for the National Estuarine Research Reserve (NERR) System by the National Oceanic and Atmospheric Administration (NOAA) in 1980, and presently, there are only two NERR throughout the Great Lakes regions of North America. In 1995, data loggers were installed at four locations within the estuary for the NERR System-Wide Monitoring Program (SWMP). The Berlin Road (BR) station in the upstream area far south of the estuary was chosen for this research, because it can better measure discharges into the main reservoir, as it is upstream from the effect of hydro-dynamism associated with the mouth of the estuary. Another reason was because of the presence of the USGS gauge station at the BR station where streamflow calibration data were collected.

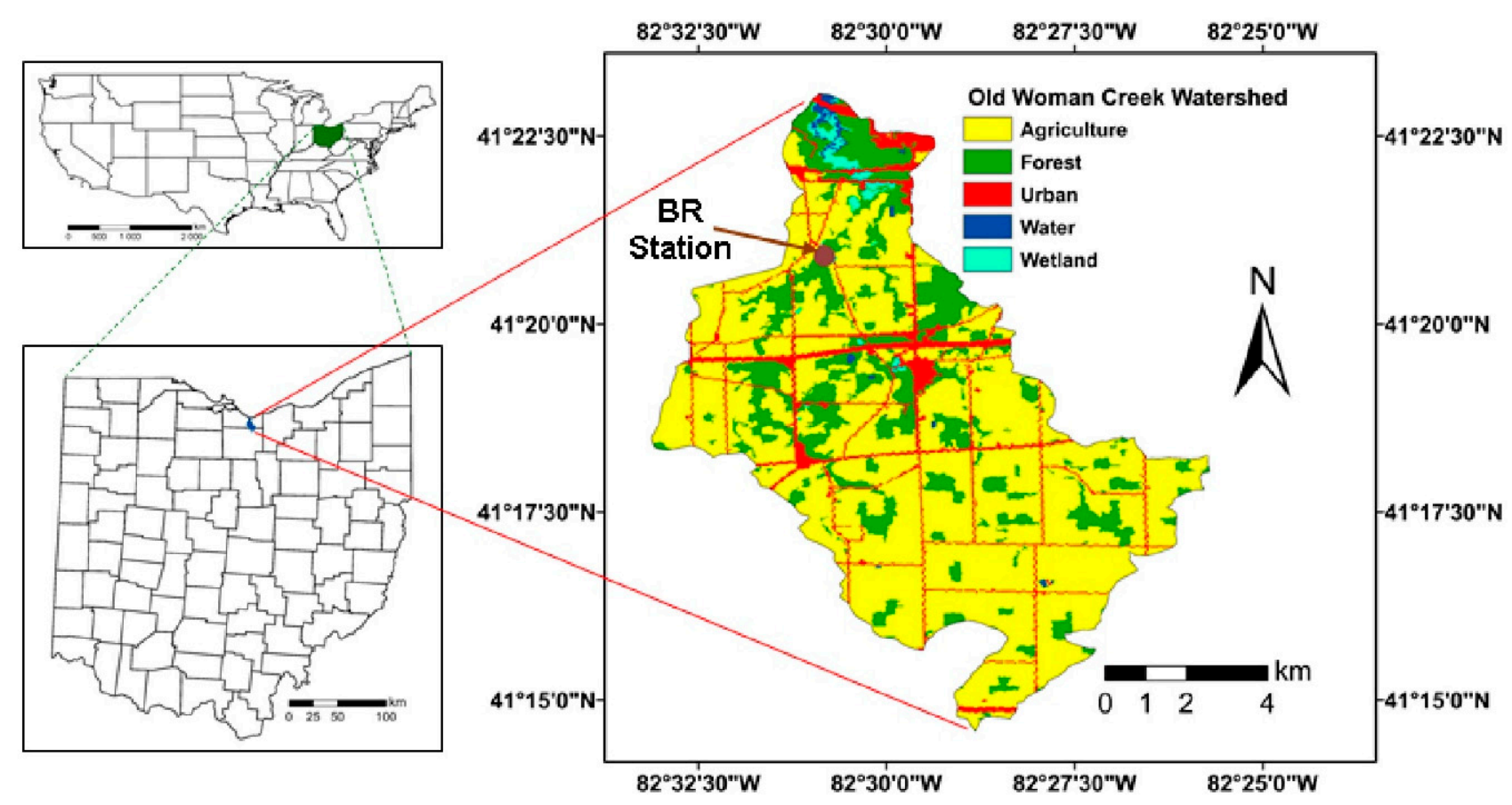

Figure 1. Location map of Old Woman Creek watershed.

\subsection{Data Acquisition}

\subsubsection{SWAT Data Acquisition and Preparation}

The following data were acquired and used for the hydrological modeling of OWC watershed: OWC shapefile, climate and weather data, digital elevation model (DEM), slope map, land use/land cover map, and digital soil data.

The Ohio state shapefile was obtained from the data catalogue website (https:// catalog.data.gov/dataset/tiger-line-shapefile accessed on 22 August 2018) from which the OWC shapefile was extracted to produce all the GIS layers used for this modeling. The $10 \mathrm{~m}$ spatial resolution digital elevation model (DEM) of Ohio state was downloaded from national resources conservation services at https: / / datagateway.nrcs.usda.gov accessed on 31 January 2019. The $30 \mathrm{~m}$ resolution LULC data used were downloaded from the National Land Cover Database at https:/ / www.mrlc.gov/data/type/land-cover accessed on 31 January 2019. Digital soil data of Ohio state available at the national resources conservation services website as Soil Survey Geographic (SSURGO) database (https:/ / www.nrcs.usda.gov accessed on 31 January 2021) were used in this work. For the model 
calibration and validation, the streamflow measurement was obtained from the USGS gauge station at Berlin Road, OWC watershed, Ohio while the water quality data were obtained from the water quality lab, Heidelberg University, Tiffin, Ohio. The SWAT model was run in ArcSWAT GIS interface developed and made available by the Texas A\&M University System. The 1981-2017 PRISM climate data with a spatial resolution of $4 \times 4 \mathrm{~km}$ were downloaded from http:/ / www.PRISM.oregonstate.edu accessed on 31 January 2019. The 1981-2100 CMIP5 model ensemble consisting of the selected 20 GCMs with spatial resolution ranging from Latitude 1.1215 to 2.7906 and Longitude 1.1215 to 3.75 (Table 1) was downloaded from the climate data store (CDS) catalogue, downscaled to $4 \times 4 \mathrm{~km}$ resolution, and bias-corrected using the distribution-based scaling (DBS) method described by Yang et al. [18]. The 20 GCMs from CMIP5 at RCP 8.5 only were selected for the analysis to test the performance of each model and identify the most suitable GCM models for the OWC watershed simulation. The 20 GCMs selected consist of 19 GCMs available at the global users in the Copernicus climate change service (C3S_422_Lot1_SMHI project) and one North American GCM (CAN-ESM2). The calibration and validation data were available from 2015-2017, and hence, the future climate window for this study starts from 2018.

Table 1. Original spatial resolution of the 20 Global Circulation Models (GCMs) used in this study (1981-2100).

\begin{tabular}{|c|c|c|c|c|c|c|}
\hline Institute & Model & GCM_Data & GCMName & Remarks & Latitude & Longitude \\
\hline CSIRO-BOM & ACCESS1-0 & ACCESS1-0 & CSIS10 & $\begin{array}{l}\text { Centre for Australian Weather } \\
\text { and Climate Research } \\
\text { (CAWCR) }\end{array}$ & 1.25 & 1.875 \\
\hline CSIRO-BOM & ACCESS1-3 & ACCESS1-3 & CSIS13 & $\begin{array}{l}\text { Centre for Australian Weather } \\
\text { and Climate Research } \\
\text { (CAWCR) }\end{array}$ & 1.25 & 1.875 \\
\hline $\mathrm{BCC}$ & CSM1-1 & bcc-csm1-1 & BCCSM1 & Beijing Climate Center & 2.7906 & 2.8125 \\
\hline BNU & ESM & BNU-ESM & BNUESM & Beijing Normal University & 2.7906 & 2.8125 \\
\hline CCCma & CanESM2 & CanESM2 & CanESM & $\begin{array}{c}\text { Canadian Centre for Climate } \\
\text { Modelling and Analysis, } \\
\text { Victoria, BC, Canada }\end{array}$ & 2.7906 & 2.8125 \\
\hline CNRM & CNRM-CM5 & CNRM-CM5 & CNRCM5 & $\begin{array}{l}\text { National Centre for } \\
\text { Meteorological } \\
\text { Research, France }\end{array}$ & 1.4008 & 1.40625 \\
\hline CSIRO-QCCCE & CSIRO-Mk3-6-0 & CSIRO-Mk3-6-0 & CSI360 & $\begin{array}{l}\text { Commonwealth Scientific and } \\
\text { Industrial Research } \\
\text { Organization/Queensland } \\
\text { Climate Change Centre of } \\
\text { Excellence (CSIRO-QCCCE) }\end{array}$ & 1.8653 & 1.875 \\
\hline SMHI & EC-EARTH & EC-EARTH & EEARTH & $\begin{array}{l}\text { A European community } \\
\text { Earth-System Model, led by } \\
\text { SMHI, Sweden }\end{array}$ & 1.1215 & 1.125 \\
\hline GFDL & CM3 & GFDL-CM3 & GFDCM3 & $\begin{array}{l}\text { Geophysical Fluid Dynamics } \\
\text { Laboratory, NOAA }\end{array}$ & 2 & 2.5 \\
\hline GFDL & ESM2G & GFDL-ESM2G & GFDM2G & $\begin{array}{l}\text { Geophysical Fluid Dynamics } \\
\text { Laboratory, NOAA }\end{array}$ & 2.0225 & 2.0 \\
\hline GFDL & ESM2M & GFDL-ESM2M & GFDM2M & $\begin{array}{c}\text { Geophysical Fluid Dynamics } \\
\text { Laboratory, NOAA }\end{array}$ & 2.0225 & 2.5 \\
\hline $\mathrm{MOHC}$ & HadGEM2-CC & HadGEM2-CC & $\mathrm{HAD} 2 \mathrm{CC}$ & $\begin{array}{c}\text { Met Office Hadley Centre, } \\
\text { Hadley Global Environment } \\
\text { Model, UK }\end{array}$ & 1.25 & 1.875 \\
\hline MOHC & HadGEM2-ES & HadGEM2-ES & HAD2ES & $\begin{array}{c}\text { Met Office Hadley Centre, } \\
\text { Hadley Global Environment } \\
\text { Model, UK }\end{array}$ & 1.25 & 1.875 \\
\hline
\end{tabular}


Table 1. Cont.

\begin{tabular}{|c|c|c|c|c|c|c|}
\hline Institute & Model & GCM_Data & GCMName & Remarks & Latitude & Longitude \\
\hline INM & $\mathrm{CM} 4$ & INMCM4 & INMCM4 & $\begin{array}{c}\text { Russian Institute for } \\
\text { Numerical Mathematics } \\
\text { Climate Model Version } 4\end{array}$ & 1.5 & 2 \\
\hline IPSL & CM5A-LR & IPSL-CM5A-LR & IPSALR & $\begin{array}{l}\text { Institut Pierre Simon } \\
\text { Laplace, France }\end{array}$ & 1.8947 & 3.75 \\
\hline IPSL & CM5A-MR & IPSL-CM5A-MR & IPSAMR & $\begin{array}{l}\text { Institut Pierre Simon } \\
\text { Laplace, France }\end{array}$ & 1.2676 & 2.5 \\
\hline IPSL & IPSL-CM5B-LR & IPSL-CM5B-LR & IPSBLR & $\begin{array}{l}\text { Institut Pierre Simon } \\
\text { Laplace, France }\end{array}$ & 1.8947 & 3.75 \\
\hline MPI & ESM-LR & MPI-ESM-LR & MPIMLR & $\begin{array}{c}\text { Max Planck } \\
\text { Institute, Germany }\end{array}$ & 1.8653 & 1.875 \\
\hline MPI & MPI-ESM-MR & MPI-ESM-MR & MPIMMR & $\begin{array}{c}\text { Max Planck } \\
\text { Institute, Germany }\end{array}$ & 1.8653 & 1.875 \\
\hline NCC & NorESM1-M & NorESM1-M & NORM1M & $\begin{array}{l}\text { Norwegian Climate Centre } \\
\text { Earth System Model M }\end{array}$ & 1.8947 & 2.5 \\
\hline
\end{tabular}

\subsubsection{SWAT Model}

The widely used Soil and Water Assessment Tool (SWAT) is a watershed based hydrological modeling framework produced by Jeff Arnold by upgrading the Simulator for Water in Rural Basins (SWRRB). It was primarily produced for the United States Department of Agriculture, Agricultural Research Services (USDA-ARS) to appraise the influence of environmental pollution and land management practices on water quality. It can simulate the effect of management practices on streamflow and water quality within a large basin with dynamic soil and management practices for a long-time frame [19].

SWAT is capable of efficient simulation on a daily, monthly, and yearly time scale using spatial and meteorological data as input. Arnold et al. [20] gave a detailed account of SWAT parameters and units, some of which include weather, crop yield, soil types, fertilizer application, and hydrological processes. In SWAT modeling, the whole basin is divided into reaches that are further divided into the smallest units called the hydrological response units (HRU). The spatial data needed for hydrological modeling are uploaded into SWAT through the ArcSWAT 2012 graphical interface [21,22].

\subsubsection{Model Set-Up, Calibration, and Validation}

The ArcSWAT 2012 was employed for the setting up of SWAT for hydrological models. To prepare the model for watershed delineation, drainage, and slope definition, OWC watershed DEM was loaded, and digital stream data added to establish the stream network. The SWAT inbuilt minimum threshold approach based on the minimum area function was used to automatically generate the outlets for the sub-basins, and other outlets were manually added at important locations including one outlet leading to the location of the USGS gauge station (Berlin Road) where calibration and validation data were obtained. OWC watershed was delineated with a size of $66.95 \mathrm{~km}^{2}$ and a total of 103 sub-basins. Sub-basins characterization involves the creation of 3 slope classes, which include 3, 3-15, and $>15 \%$, and 12 land use classes, which include barren land, open waters, developed high intensity, developed low intensity, developed open space, developed medium intensity, hay/pasture, woody wetlands, evergreen forest, cultivated crops, herbaceous and deciduous forest, and 81 soil classes (Based on SSURGO classification). Land use, slope, and soil were reclassified, and 479 HRUs were created to complete the HRU definition process. SWAT editor was used to encode management practices for the different crops (corn, soya, and wheat) planted in the watershed based on the actual conditions on agricultural land in OWC watershed. The management practices include crop rotation, tillage, fertilizer application, planting time, and harvesting time. 
PRISM temperature (min, max, and daily average) and precipitation (1981-2017) were added to the setup, other climate parameters including wind speed, solar radiation, and relative humidity were generated by SWAT for the modeling. The sensitivity of the SWAT parameters to water quality variables was ascertained, and a total of the 56 most sensitive parameters were selected for calibration.

The selected parameters were optimized by modifying the multi-objective evolutionary algorithm method developed by Confesor and Whittaker [23]. The curve number for each of the 479 HRU was calibrated separately, and the soil evaporation compensation factor for each of the 12 land use groups was calibrated separately. The limits of the parameters to be optimized were fixed based on the results obtained from sensitivity analysis. The USGS gauging station at Berlin Road offers the most consistent daily streamflow measurement record between 2015 and 2017, and thus, the model calibration period was set to 5 May 2005-31 December 2016 (607 observations) and the validation period set to 1 January-31 December 2017 (365 observations). A warm-up period of 3 years was used in all simulations. The calibrated and validated variables are streamflow, sediment (TSS), organic nitrogen, mineral phosphorus (SRP), organic phosphorus, total nitrogen, and total phosphorus. Three water quality variables including chlorophyll a, CBOD, and dissolved oxygen were not calibrated because of lack of data, and this may impact the results reported for these three variables.

The generic algorithm package (genalg) in $\mathrm{R}$ statistical language [24] was modified and used to randomly create the first 1000 solutions of the parent population from which the 1000 solutions of the child population were generated using five objective functions (flow, TSS, total p, SRP, and total $n$ ). The calibration parameters were modified on the fly, and SWAT was run as an R subroutine for each of the solutions and the iteration was stopped at 200. A total of 201,000 SWAT runs were made with 200 iterations.

\subsubsection{Objective Function and Model Performance Evaluation}

The five objective functions (flow, TSS, total $p$, SRP, and total $n$ ) were used to keep the average root mean square error (RMSE) of the observed versus simulated at minimum. The RMSE equation is given as:

$$
R M S E=\left(\frac{1}{n} \sum_{i=1}^{n}\left(Q_{s m, i}-Q_{o b, i}\right)^{2}\right)^{0.5}
$$

The performance of the calibrated SWAT model was evaluated by comparing the simulated with the observed variables using three statistical indices: percentage bias/percentage error (PBAS (\%)), Nash-Sutcliffe model efficiency (NSE) [25] and coefficient of $\mathrm{R}^{2}$.

$$
\begin{gathered}
\text { PBIAS }[\%]=\frac{\sum_{i=1}^{n}(o b-s m) \times 100}{\sum_{i=1}^{n} o b} \\
N S E=1-\frac{\frac{1}{n} \sum_{i=1}^{n}\left(Q_{s m, i}-Q_{o b, i}\right)^{2}}{\frac{1}{n} \sum_{i=1}^{n}\left(Q_{s m, i}-Q_{\overline{o b}, i}\right)^{2}} \\
\mathrm{R}^{2}=\frac{\left[\left(\sum_{i=1}^{n}(o b-\overline{o b})\right)(s m-\overline{s m})\right]^{2}}{\sum_{i=1}^{n}(o b-\overline{o b})^{2} \sum_{i=1}^{n}(s m-\overline{s m})^{2}}
\end{gathered}
$$

where $Q_{O b}$ and $Q_{S m}$ are the observed (measured) and the simulated daily streamflow at a given time $i$, and $n$ represents the total number of observations for the simulation.

NSE ranges from negative infinity to 1 , with 1 indicating a perfect match between the observed and simulated. 


\subsection{Scenario Simulations}

A total of 141 annual simulations were made in this work to analyze the response of 10 water quality variables. For the historical (first) climate window (1985-2014), a total of 21 simulations were made. Only one simulation was run with PRISM climate data, 20 simulations were run with $20 \mathrm{GCMs}$, and the results were compared to establish the extent to which CMIP5 GCMs can reproduce the actual (PRISM climate) results. For the Scenario 1 of the current to near future (2018-2045), mid-century (2046-2075), and latecentury (2076-2100) climate windows, a total of 60 simulations were made using 20 GCMs in each climate window with constant (current) LULC data applied across all the climate windows. For Scenario 2 of the current to near future (2018-2045), mid-century (2046-2075), and late-century (2076-2100) climate windows, a total of 60 simulations were also made using 20 GCMs in each climate window with the respective projected LULC applied for each climate window, and the results of the two scenarios were compared.

\section{Results}

\subsection{Historical (PRISM) and Projected (CMIP5) Climate Forcing}

The PRISM and GCMs climate forcing used for the simulations of flow and water quality variables in OWC watershed for the 21st century are shown in Figures 2 and 3. For the historical climate window, PRISM results were averaged to remove inter-annual variability within the climate window. For each of the four climate windows, the results of the simulations made from the 20 different GCMs were first averaged across the model to remove inter model variability, and the results averaged to remove inter annual variability within the climate window. Comparison of precipitation data in the historical climate window shows that GCMs slightly underestimated precipitation with an annual average value of $937.7 \mathrm{~mm}$ compared to the actual (PRISM climate) with an annual average value of $962.4 \mathrm{~mm}$, but the underestimation is statistically insignificant as the error bar from GCMs' results overlaps PRISM result. The GCMs' precipitation increases almost linearly from $937.7 \mathrm{~mm}$ in the historical climate window to $1060.7 \mathrm{~mm}$ in the late-century climate window. The percentage increase in average annual precipitation relative to the historical climate window for the current-future, mid-century, and late-century climate windows are $4.2,7.6$, and $13.1 \%$ respectively.

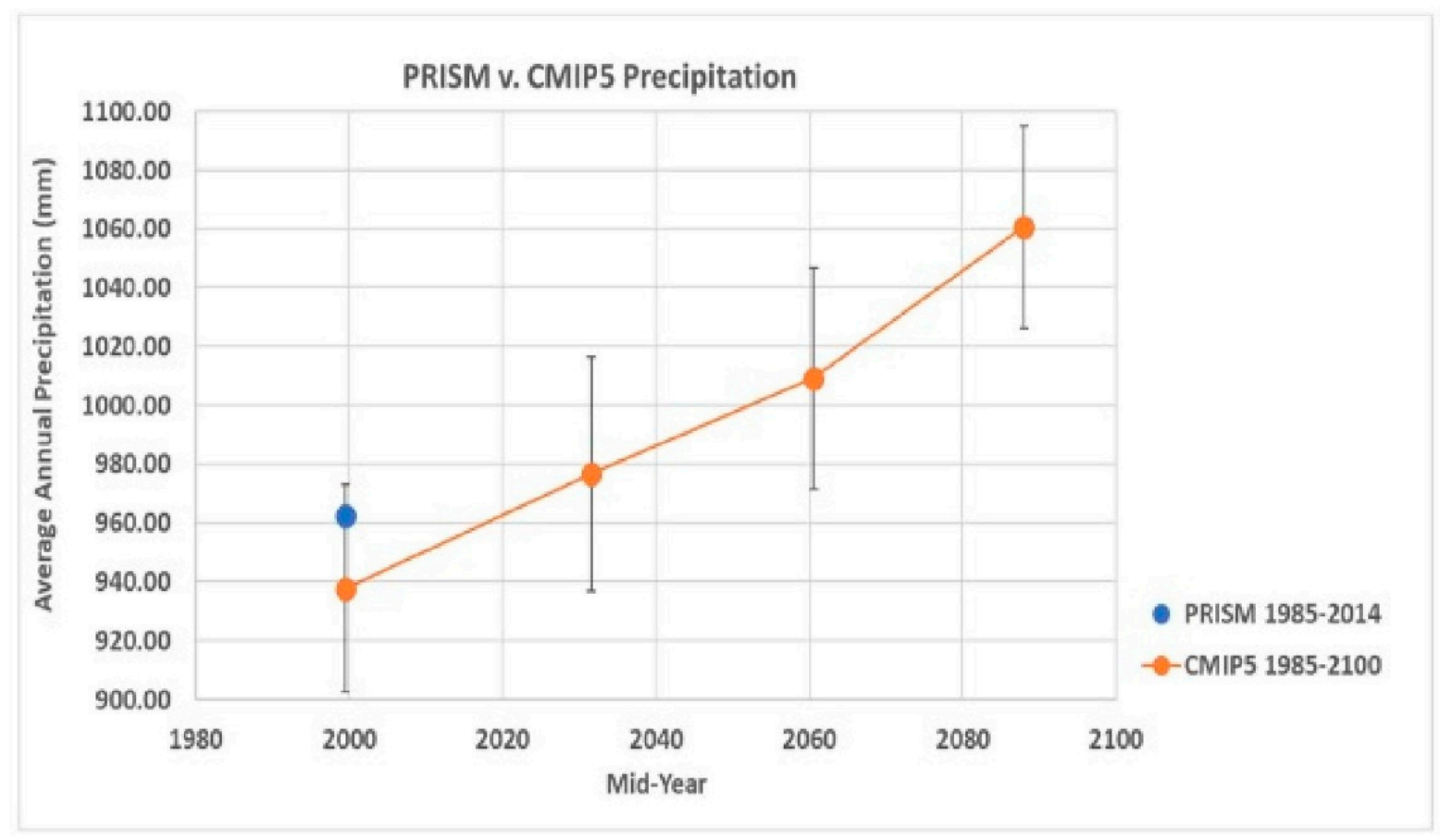

Figure 2. PRISM vs. Average of 20 CMIP5 GCMs precipitation. 


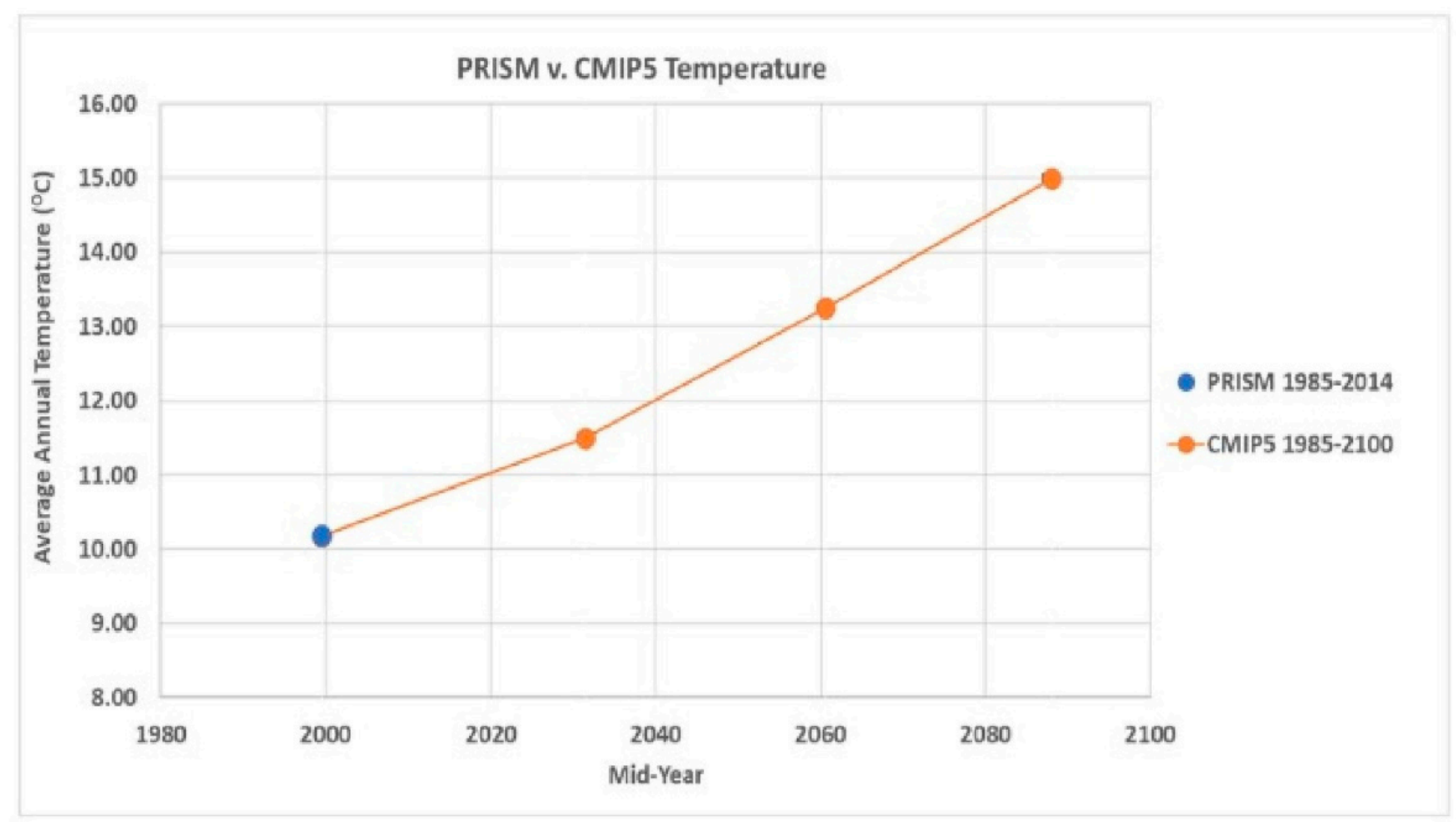

Figure 3. PRISM vs. Average of 20 CMIP5 GCMs temperature.

For the historical climate window, PRISM and CMIP5 GCMs temperatures are almost the same with values of 10.19 and $10.18{ }^{\circ} \mathrm{C}$, respectively. CMIP5 GCMs' temperature increases almost linearly from the historical climate window with an annual average of $10.18{ }^{\circ} \mathrm{C}$ to the last climate window with an annual average of $14.99{ }^{\circ} \mathrm{C}$. The percentage increase in average annual temperature relative to the historical climate window for the current-future, mid-century, and late-century climate windows are 12.9, 30.1, and $47.3 \%$ respectively.

The error bars were constructed from the standard deviation of the projected climate data and show the degree of variability in each data. The variability observed between the average of the 20 GCMs' result and the PRISM data is statistically insignificant as shown by the overlapping error bars (Figures 2 and 3). In short, the average of 20 GCMs is consistent with the PRISM climate data for the OWC watershed and can be used to run simulations for the future scenarios.

\subsection{Land Use Forcing}

The OWC watershed is primarily agricultural, and the LULC has not been changing significantly over the past years. The land use forcing in this analysis is shown in Table 2, and it represents the average over the climate window. The land use data averaged over the period 1985-2014 were used for the simulations in the historical climate window. For Scenario 1, the baseline calibration land use data, which represents the average of 2015-2017, was used as a constant land use data for simulations for all climate windows. For Scenario 2, the projected land use data, generated using joint MLP-CA Markov model and averaged over the respective climate window, were used for all the simulations. The agricultural land in the OWC watershed is projected to decrease across the century, while urbanization is projected to increase slightly across the century (Tables 2 and 3). 
Table 2. Land use/land cover (LULC) forcing used in the simulation.

\begin{tabular}{|c|c|c|c|c|c|c|}
\hline Climate Window & Mid-Year & Agriculture (\%) & Forest (\%) & Urban (\%) & Water (\%) & Wetland (\%) \\
\hline PRISM 1985-2014 & 1999.5 & 65.42 & 25.14 & 8.12 & 0.50 & 0.82 \\
\hline $\begin{array}{l}20 \text { CMIP5 GCMs } \\
\text { 1985-2014 }\end{array}$ & 1999.5 & 65.42 & 25.14 & 8.12 & 0.50 & 0.82 \\
\hline $\begin{array}{l}20 \text { CMIP5 GCMs Scenario } \\
\text { 1_2018-2100 }\end{array}$ & 2031.5 & 65.18 & 24.95 & 8.44 & 0.62 & 0.81 \\
\hline $\begin{array}{l}20 \text { CMIP5 GCMs Scenario } \\
\text { 2_2018-45 }\end{array}$ & 2031.5 & 64.38 & 25.02 & 9.02 & 0.73 & 0.84 \\
\hline $\begin{array}{l}20 \text { CMIP5 GCMs Scenario } \\
\text { 2_2046-75 }\end{array}$ & 2060.5 & 63.16 & 25.30 & 9.96 & 0.73 & 0.84 \\
\hline $\begin{array}{c}20 \text { CMIP5 GCMs Scenario } \\
\text { 2_2076-00 }\end{array}$ & 2088 & 61.58 & 26.01 & 10.82 & 0.73 & 0.85 \\
\hline
\end{tabular}

Table 3. Percentages change in forcing from the historical climate window.

\begin{tabular}{cccc}
\hline Forcing & $\mathbf{( W 2 - W 1 )} \%$ & (W3-W1) & (W4-W1) \% \\
\hline Precipitation & 4.2 & 7.6 & 13.1 \\
\hline Temperature & 12.9 & 30.1 & 47.3 \\
\hline Agriculture & -1.04 & -2.26 & -3.84 \\
\hline Urbanization & 0.9 & 1.84 & 2.7 \\
\hline
\end{tabular}

\subsection{PRISM and CMIP5 GCMs Inter-Model Variability Results (1985-2014)}

The results of the simulations made with PRISM and the 20 GCMs for flow and nine water quality variables are shown in boxplots in the Appendix A, while the summary of the statistics of the boxplots and the mean are shown in Table 4. Each of the $20 \mathrm{GCMs}^{\prime}$ results and the average of the $20 \mathrm{GCMs}$ ' results was compared with the PRISM result, and it was found that the results of each of the 20 GCMs shows different variability with PRISM result across all variables but the average of the $20 \mathrm{GCMs}$ ' results is more consistent with the PRISM result across all variables when compared along the mean and median values. For all the water quality variables studied, the average of the 20 GCMs' results slightly and consistently overestimated the 10 variables of interest within the error of SWAT simulations. The variability observed in the average of $20 \mathrm{GCMs}^{\prime}$ results is smaller than that of the PRISM result. This is because the GCMs' results represent the average of 20 models, while the PRISM result is one model result. In Table 4, the mean and median values for the average of 20 GCMs $\left(0.49,0.48 \mathrm{~m}^{3} / \mathrm{s}\right)$ and PRISM $\left(0.46,0.47 \mathrm{~m}^{3} / \mathrm{s}\right)$ for flow are consistent. For sediment, the mean and the median values for the average of 20 GCMs $(5612,5530$ tons) and PRISM (5022, 4919 tons) are also consistent. For all the 10 variables of interest, the mean of the average of the 20 GCMs' results is slightly and consistently higher than that of the PRISM results. 
Table 4. Flow and WQ comparison between PRISM and average of 20 CMIP5 GCMs (1985-2014).

\begin{tabular}{|c|c|c|c|c|c|c|c|c|c|c|}
\hline & \multicolumn{2}{|c|}{ Streamflow $\left(\mathrm{m}^{3} / \mathrm{s}\right)$} & \multicolumn{2}{|c|}{ Sediment (tons) } & \multicolumn{2}{|c|}{$\begin{array}{c}\text { Organic } \\
\text { Nitrogen }(\mathbf{k g})\end{array}$} & \multicolumn{2}{|c|}{$\begin{array}{c}\text { Organic } \\
\text { Phosphorus (kg) }\end{array}$} & \multicolumn{2}{|c|}{$\begin{array}{c}\text { Mineral } \\
\text { Phosphorus (kg) }\end{array}$} \\
\hline & $\begin{array}{l}\text { CMIP5 } \\
\text { Avg. }\end{array}$ & PRISM & $\begin{array}{l}\text { CMIP5 } \\
\text { Avg. }\end{array}$ & PRISM & $\begin{array}{l}\text { CMIP5 } \\
\text { Avg. }\end{array}$ & PRISM & $\begin{array}{l}\text { CMIP5 } \\
\text { Avg. }\end{array}$ & PRISM & $\begin{array}{l}\text { CMIP5 } \\
\text { Avg. }\end{array}$ & PRISM \\
\hline mean & 0.49 & 0.46 & 5612 & 5022 & 38,508 & 35,955 & 9949 & 9353 & 2020 & 1848 \\
\hline std & 0.04 & 0.19 & 659 & 2744 & 3350 & 16,130 & 947 & 4053 & 225 & 616 \\
\hline $\min$ & 0.40 & 0.14 & 4362 & 783 & 32,802 & 8060 & 8318 & 2344 & 1705 & 722 \\
\hline 0.25 & 0.46 & 0.33 & 5210 & 3250 & 35,908 & 24,908 & 9149 & 6230 & 1829 & 1442 \\
\hline 0.50 & 0.48 & 0.47 & 5530 & 4919 & 37,731 & 34,775 & 9796 & 9422 & 2030 & 1910 \\
\hline 0.75 & 0.53 & 0.60 & 6114 & 6948 & 40,318 & 43,675 & 10,621 & 11,409 & 2120 & 2264 \\
\hline $\max$ & 0.58 & 0.91 & 6944 & 11,754 & 44,516 & 67,890 & 11,638 & 16,998 & 2639 & 2953 \\
\hline \multirow[t]{3}{*}{ Outliers } & NA & NA & NA & NA & NA & NA & NA & NA & 2639.40 & NA \\
\hline & \multicolumn{2}{|c|}{$\begin{array}{l}\text { Chlorophyll } \\
\text { a (kg) }\end{array}$} & \multicolumn{2}{|c|}{ CBOD (kg) } & \multicolumn{2}{|c|}{$\begin{array}{c}\text { Dissolved } \\
\text { Oxygen (kg) }\end{array}$} & \multicolumn{2}{|c|}{ Total Nitrogen (kg) } & \multicolumn{2}{|c|}{$\begin{array}{c}\text { Total } \\
\text { Phosphorus (kg) }\end{array}$} \\
\hline & $\begin{array}{l}\text { CMIP5 } \\
\text { Avg. }\end{array}$ & PRISM & $\begin{array}{l}\text { CMIP5 } \\
\text { Avg. }\end{array}$ & PRISM & $\begin{array}{l}\text { CMIP5 } \\
\text { Avg. }\end{array}$ & PRISM & $\begin{array}{l}\text { CMIP5 } \\
\text { Avg. }\end{array}$ & PRISM & $\begin{array}{l}\text { CMIP5 } \\
\text { Avg. }\end{array}$ & PRISM \\
\hline mean & 685 & 614 & 711,384 & 676,462 & 64,550 & 63,389 & 111,316 & 107,745 & 11,969 & 11,201 \\
\hline std & 66 & 363 & 59,993 & 298,464 & 4661 & 22,825 & 11,479 & 45,366 & 1091 & 4630 \\
\hline $\min$ & 526 & 68 & 585,142 & 150,120 & 54,488 & 23,734 & 90,422 & 27,490 & 10,163 & 3066 \\
\hline 0.25 & 640 & 404 & 670,726 & 473,875 & 61,231 & 45,250 & 101,697 & 68,085 & 11,141 & 7682 \\
\hline 0.5 & 679 & 548 & 695,898 & 639,800 & 64,287 & 63,510 & 110,149 & 116,150 & 11,719 & 11,359 \\
\hline 0.75 & 720 & 805 & 759,646 & 830,975 & 68,018 & 77740 & 118,118 & 141,418 & 12,629 & 13,590 \\
\hline $\max$ & 843 & 1440 & 816,880 & $1,247,400$ & 74,023 & 120,440 & 136,440 & 231,150 & 14,278 & 19,558 \\
\hline Outliers & 843 & 1440 & NA & NA & NA & NA & NA & NA & NA & NA \\
\hline
\end{tabular}

$\mathrm{CBOD}=$ carbonaceous biochemical oxygen demand.

\subsection{Scenario 1 and Scenario 2 CMIP5 Inter-Model Variability Results (2018-2100)}

The statistics of the boxplots and the mean for the simulation results for the 10 variables of interest for Scenario 1 and Scenario 2 in the current-future climate windows are presented in Table 5. It should be noted that the simulated results for the water quality variables reflect the synergistic effect of flow, other mechanisms of nutrients generation within the system, and model uncertainty, which is not separable. In this study, emphasis is placed on the respected effects of the main model forcing (climate change and LULC) over other mechanisms. The results reveal slight differences between Scenario 1 and 2. The mean, median, minimum, and maximum values for streamflow in Scenario 1 are 0.52, $0.52,0.43$, and $0.62 \mathrm{~m}^{3} / \mathrm{s}$, respectively, and in Scenario 2 are $0.53,0.52,0.44$, and $0.63 \mathrm{~m}^{3} / \mathrm{s}$, respectively. The slight increase in streamflow in Scenario 2 is attributed to a small decrease $(0.8 \%)$ in agriculture and $0.58 \%$ increase in urbanization in relation to Scenario 1 . The mean sediment transport for Scenario 1 and Scenario 2 are 6235 and 6333 tons, median values are 6215 and 6249 tons, minimum values are 4717 and 4935 tons, and the maximum values are 7608 and 7888 tons, respectively. Similar trends were observed for organic nitrogen transport, organic phosphorus, chlorophyll a, CBOD, dissolved oxygen, total nitrogen, and total phosphorus, and precipitation 
Table 5. Comparison between Scenario 1 and 2 (2018-2045).

\begin{tabular}{|c|c|c|c|c|c|c|c|c|c|c|}
\hline & \multicolumn{2}{|c|}{ Streamflow $\left(\mathrm{m}^{3} / \mathrm{s}\right)$} & \multicolumn{2}{|c|}{ Sediment (tons) } & \multicolumn{2}{|c|}{$\begin{array}{c}\text { Organic } \\
\text { Nitrogen (kg) }\end{array}$} & \multicolumn{2}{|c|}{$\begin{array}{c}\text { Organic } \\
\text { Phosphorus (kg) }\end{array}$} & \multicolumn{2}{|c|}{$\begin{array}{c}\text { Mineral } \\
\text { Phosphorus (kg) }\end{array}$} \\
\hline & Scen01 & Scen02 & Scen 01 & Scen02 & Scen01 & Scen02 & Scen01 & Scen02 & Scen01 & Scen02 \\
\hline mean & 0.52 & 0.53 & 6235 & 6333 & 40,002 & 40,409 & 10,162 & 10,426 & 2000 & 1784 \\
\hline std & 0.05 & 0.05 & 717 & 706 & 4012 & 4332 & 1002 & 1222 & 260 & 181 \\
\hline $\min$ & 0.43 & 0.44 & 4717 & 4935 & 31,333 & 30,921 & 7918 & 7811 & 1512 & 1383 \\
\hline 0.25 & 0.49 & 0.50 & 5769 & 5821 & 37,410 & 38,315 & 9608 & 9671 & 1782 & 1703 \\
\hline 0.50 & 0.52 & 0.52 & 6215 & 6249 & 39,761 & 40,217 & 10,056 & 10,330 & 1984 & 1799 \\
\hline 0.75 & 0.55 & 0.56 & 6669 & 6798 & 42,306 & 42,776 & 10,731 & 11,061 & 2206 & 1871 \\
\hline $\max$ & 0.62 & 0.63 & 7608 & 7888 & 47,797 & 49,009 & 12,406 & 12,807 & 2455 & 2184 \\
\hline Outliers & NA & NA & NA & NA & NA & 30,921 & 7918 & NA & NA & 1383 \\
\hline \multirow[t]{3}{*}{ Outliers } & NA & NA & NA & NA & NA & NA & NA & NA & NA & 2184 \\
\hline & \multicolumn{2}{|c|}{$\begin{array}{l}\text { Chlorophyll } \\
\text { a (kg) }\end{array}$} & \multicolumn{2}{|c|}{ CBOD (kg) } & \multicolumn{2}{|c|}{$\begin{array}{c}\text { Dissolved } \\
\text { Oxygen (kg) }\end{array}$} & \multicolumn{2}{|c|}{ Total Nitrogen (kg) } & \multicolumn{2}{|c|}{$\begin{array}{c}\text { Total } \\
\text { Phosphorus (kg) }\end{array}$} \\
\hline & Scen01 & Scen02 & Scen01 & Scen02 & Scen01 & Scen02 & Scen01 & Scen02 & Scen01 & Scen02 \\
\hline mean & 729 & 740 & 789,545 & 800,144 & 69,059 & 70,383 & 113,825 & 115,888 & 12,161 & 12,210 \\
\hline std & 86 & 93 & 76,029 & 83,016 & 5541 & 5442 & 8561 & 9809 & 1180 & 1385 \\
\hline $\min$ & 539 & 545 & 634,984 & 639,485 & 57,923 & 60,339 & 92,602 & 95,596 & 9430 & 9193 \\
\hline 0.25 & 684 & 694 & 734,296 & 739,323 & 65,354 & 65,988 & 108,870 & 111,399 & 11,508 & 11,415 \\
\hline 0.5 & 728 & 744 & 787,588 & 800,900 & 68,558 & 69,894 & 114,154 & 116,270 & 12,106 & 12,100 \\
\hline 0.75 & 769 & 785 & 831,460 & 845,954 & 72,442 & 73,579 & 118,622 & 120,835 & 12,808 & 12,997 \\
\hline $\max$ & 888 & 933 & 940,055 & 972,310 & 81,836 & 83,041 & 131,080 & 132,349 & 14,566 & 14,821 \\
\hline Outliers & 557 & 545 & NA & NA & NA & NA & 92,602 & 95,596 & 9430 & NA \\
\hline Outliers & 538.83 & 933.25 & NA & NA & NA & NA & NA & NA & NA & NA \\
\hline
\end{tabular}

However, a reverse (decrease) trend was observed in mineral phosphorus from Scenario 1 to Scenario 2. The mean, median, minimum, and maximum values for mineral phosphorus in Scenario 1 are 2000, 1984, 1512, and $2455 \mathrm{~kg}$, in Scenario 2 are 1784, 1799, 1383 , and $2184 \mathrm{~kg}$.

The same trend for Scenarios 1 and 2 described above was repeated in the mid-century and late-century climate windows.

\subsection{Scenario 1 and Scenario 2 Inter-Annual Variability Results (1985-2100)}

The results of the inter-annual variability analysis for Scenario 1 and Scenario 2 for all the 10 variables of interest are presented in Figures 4-13. Flow and sediment show almost linear variability for the two scenarios across the century, but the effect of LULC is greater in flow than in sediment. Organic nitrogen and organic phosphorus show nonlinear increase for the two scenarios across the century with more increase towards the end of the century. The effect of LULC is more in organic phosphorus transport than in organic nitrogen. The effect of LULC created a decrease in mineral phosphorus (SRP) transport across the century as seen in Scenario 2. Chlorophyll a, CBOD, dissolved oxygen, total nitrogen, and total phosphorus also increase nonlinearly across the century with more increase towards the end of the century in chlorophyll a, CBOD, and total phosphorus. The error bars were constructed from the standard deviation of the simulated results and show the degree of variability in each result. The variability between two results is statistically insignificant when the vertical error bars overlap and statistically significant when the vertical error bars do not overlap. For all the variables in the historical climate window, the average of 20 CMIP5 results is consistent with PRISM results, but CMIP5 overestimated the variables compared to PRISM, within the error of SWAT simulation. For all climate windows, the trend of the variables in Scenarios 1 and 2 are the same, the trend of the variable is controlled by climate, which is common to both scenarios, while the effect of LULC change is seen as the difference between the plots in the two scenarios. In Scenario 2 , the expected slight changes in land use $(-3.6 \%$ in agriculture and $+2.4 \%$ in 
urbanization) across the century generated an increase in the streamflow and other water quality variables except for mineral phosphorus. The flow and nutrients increase annually from current-future to late-century climate window. Table 6 shows the percentage change in the simulated variables relative to the historical climate window for both Scenarios 1 and 2 across the century. In the current-future climate window, the highest increase was observed in the Scenario 2 simulation for CBOD with $12.48 \%$ followed by sediment transport with $11.51 \%$. In the mid-century climate window, Scenario 2 simulation for sediment transport yielded the highest increase at $24.85 \%$ followed by CBOD at $22.71 \%$. In the late-century climate window, CBOD was highest at $43.34 \%$ followed by sediment transport at $40.13 \%$. Total phosphorus gave the lowest increase across the century, while mineral phosphorus decreased across the century.

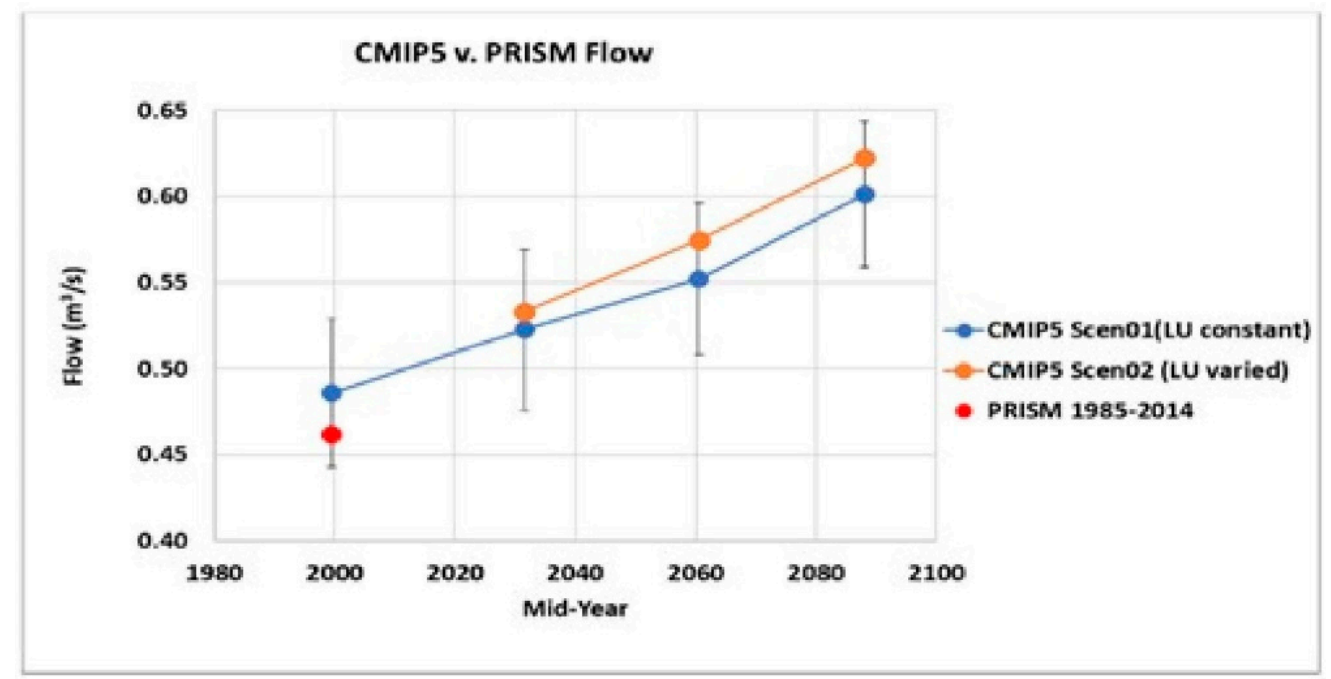

Figure 4. PRISM vs. average of 20 CMIP5 GCMs flow (2018-2100).

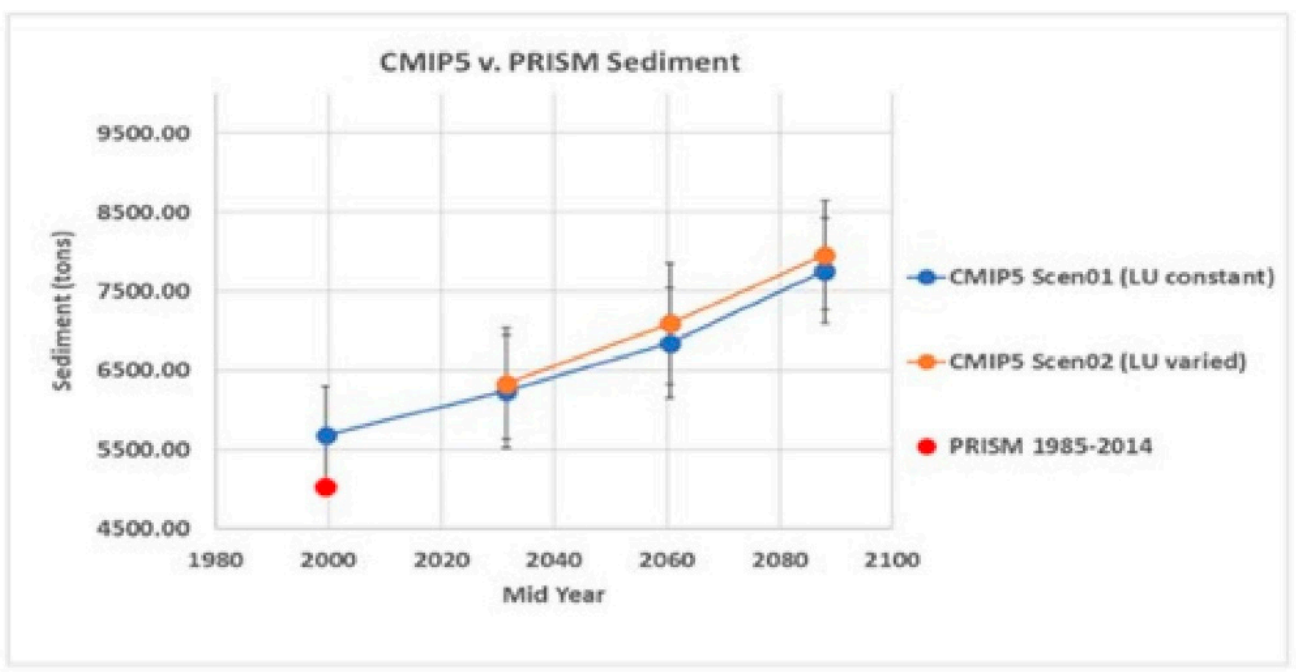

Figure 5. PRISM vs. average of 20 CMIP5 GCMs sediment (2018-2100). 


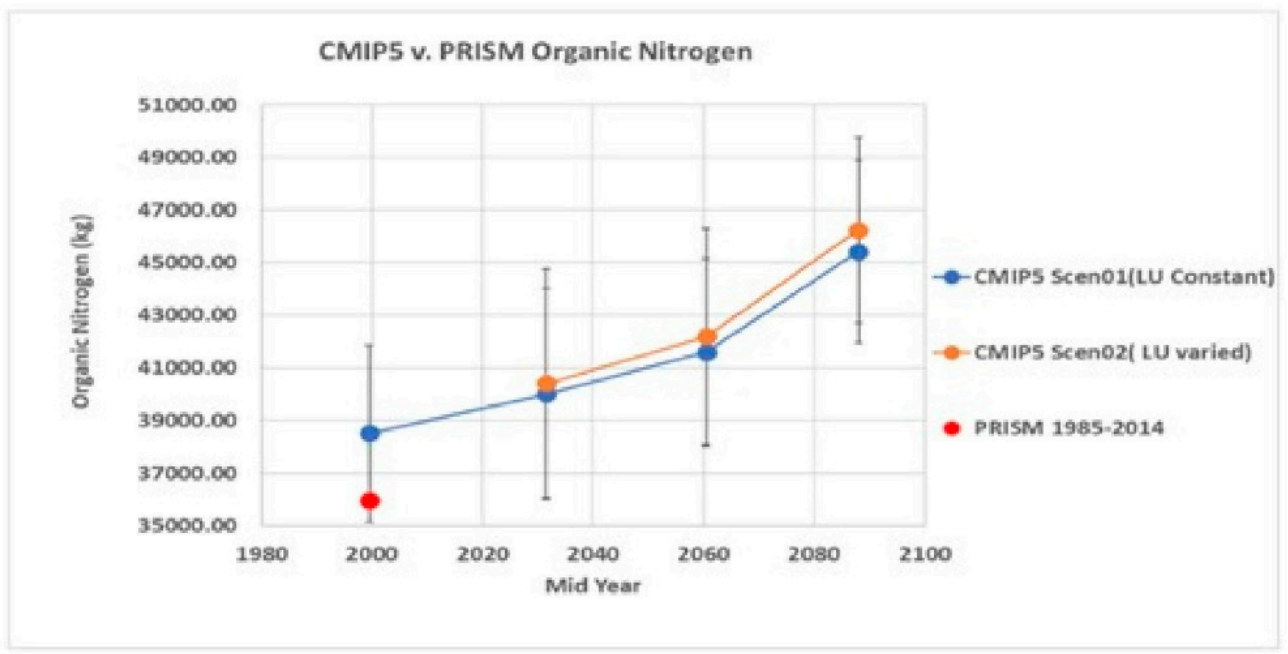

Figure 6. PRISM vs. average of 20 CMIP5 GCMs organic nitrogen (2018-2100).

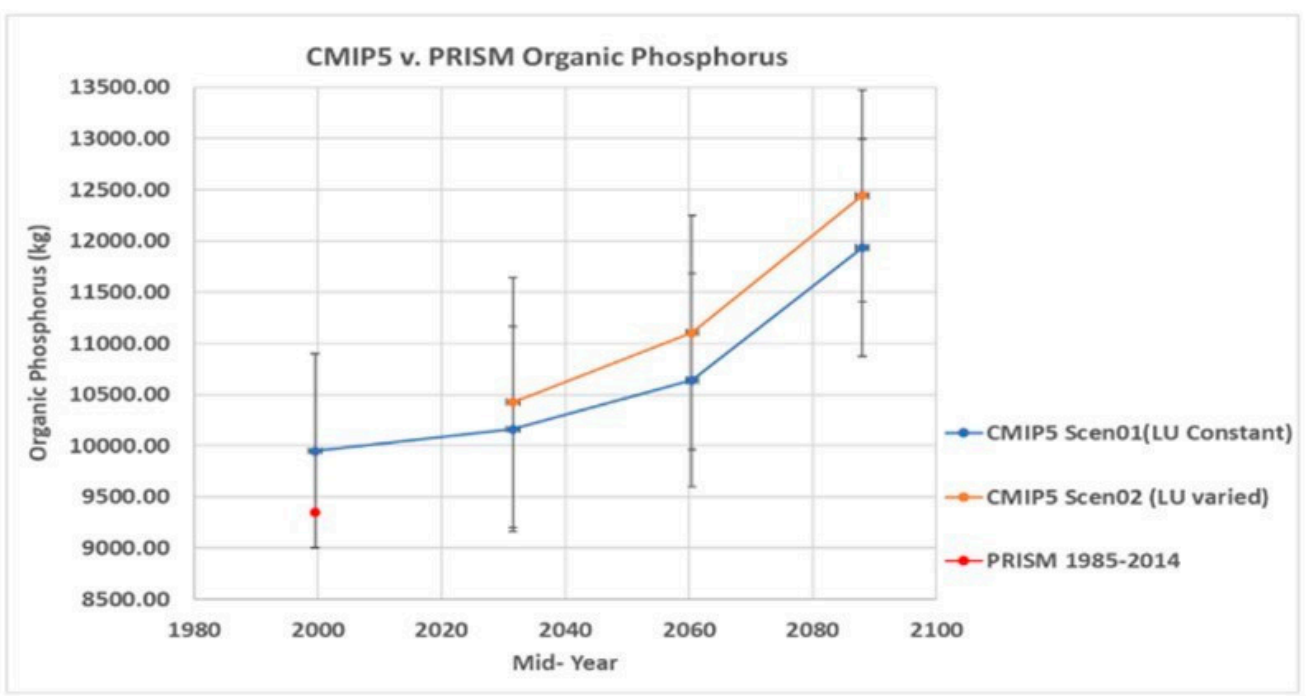

Figure 7. PRISM vs. average of 20 CMIP5 GCMs organic phosphorus (2018-2100).

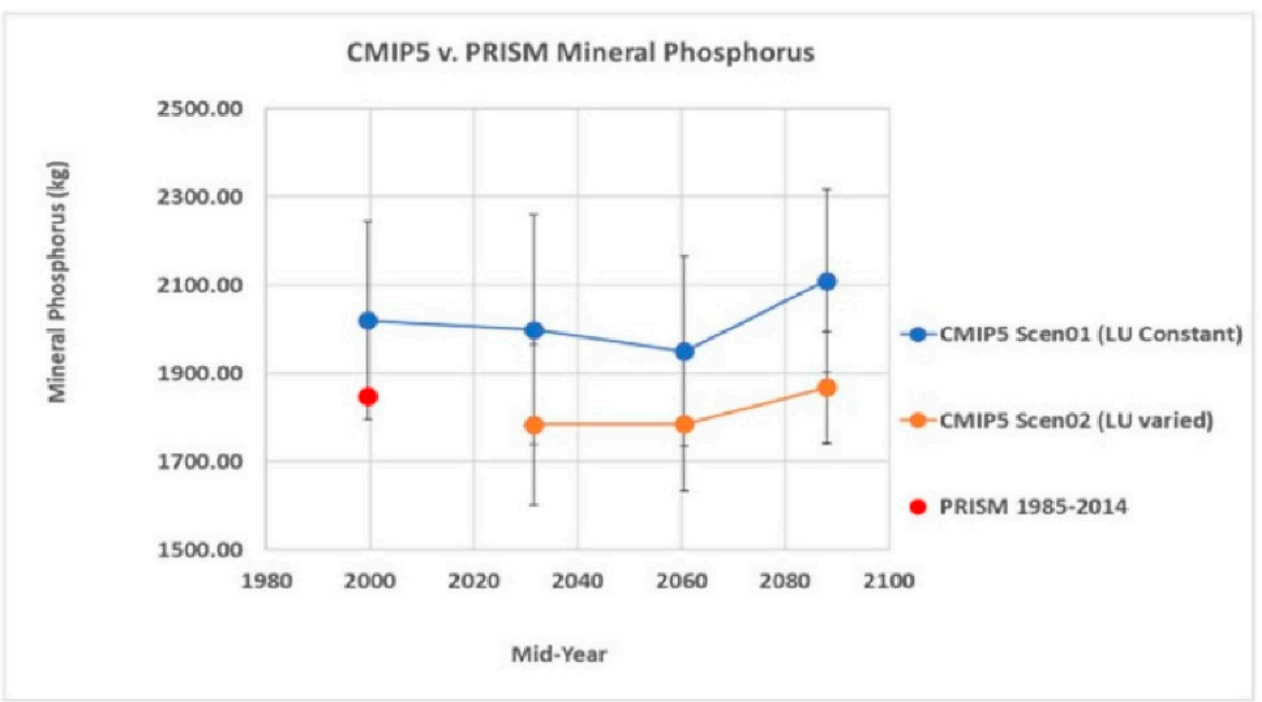

Figure 8. PRISM vs. average of 20 CMIP5 GCMs mineral phosphorus (2018-2100). 


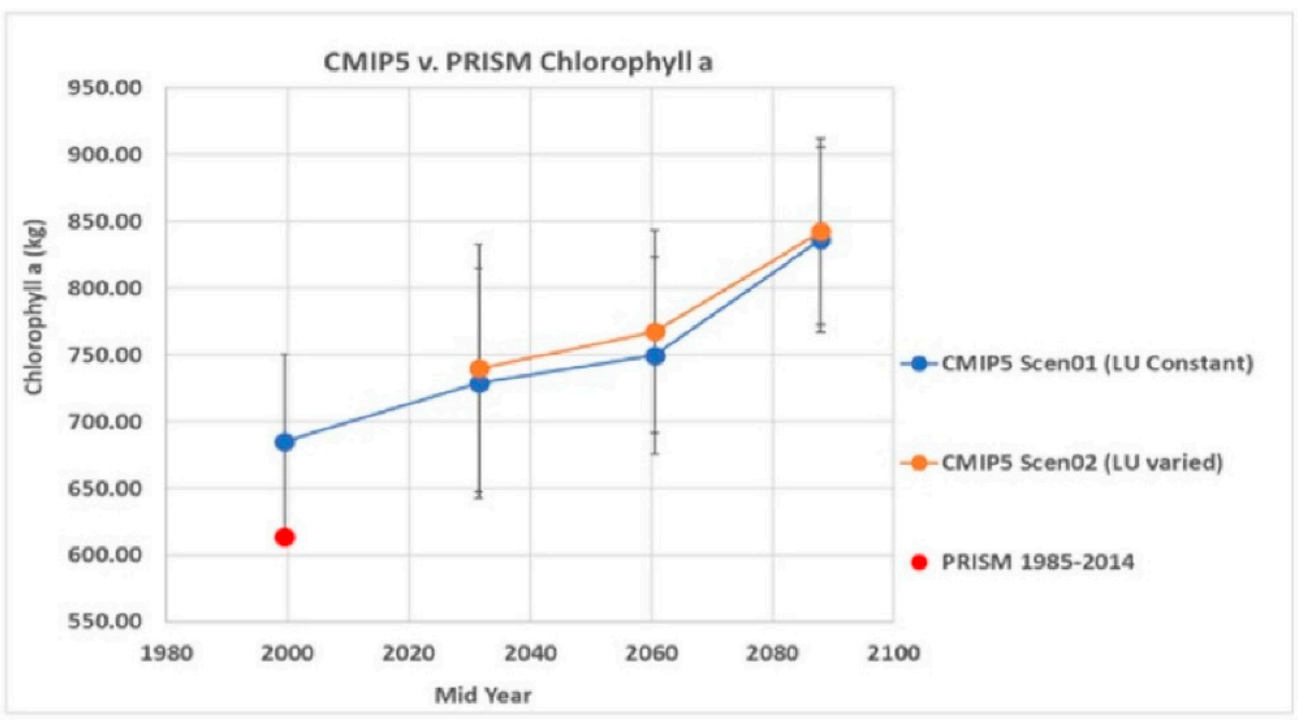

Figure 9. PRISM vs. average of 20 CMIP5 GCMs chlorophyll a (2018-2100).

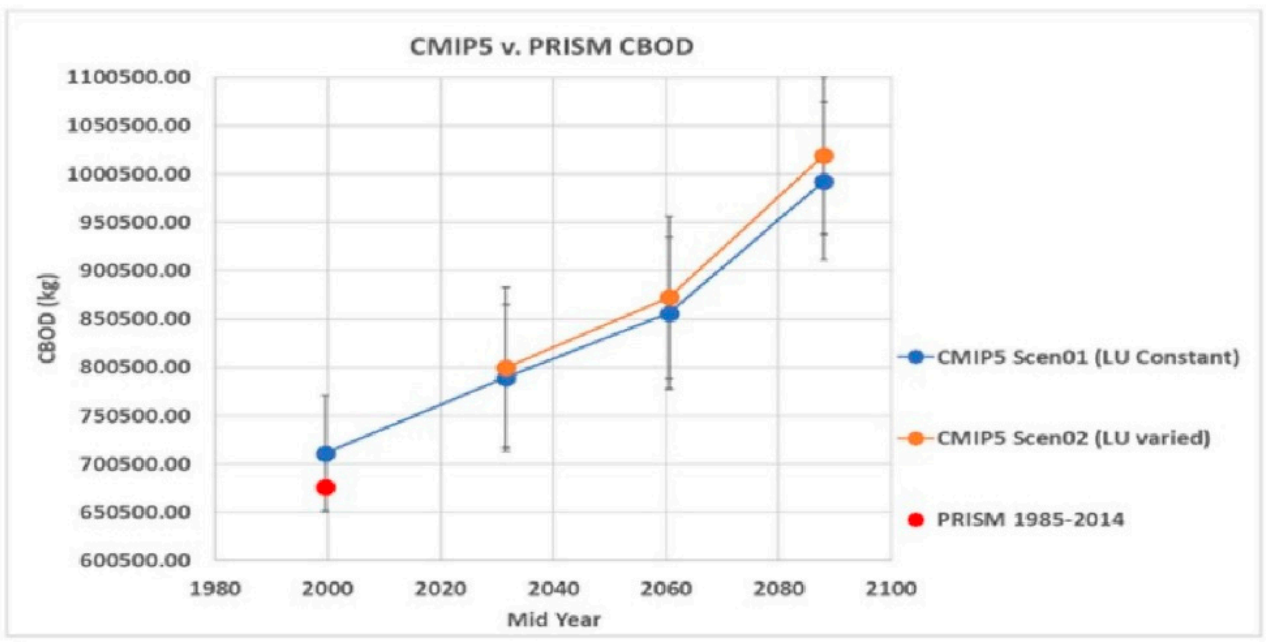

Figure 10. PRISM vs. average of 20 CMIP5 GCMs CBOD (2018-2100).

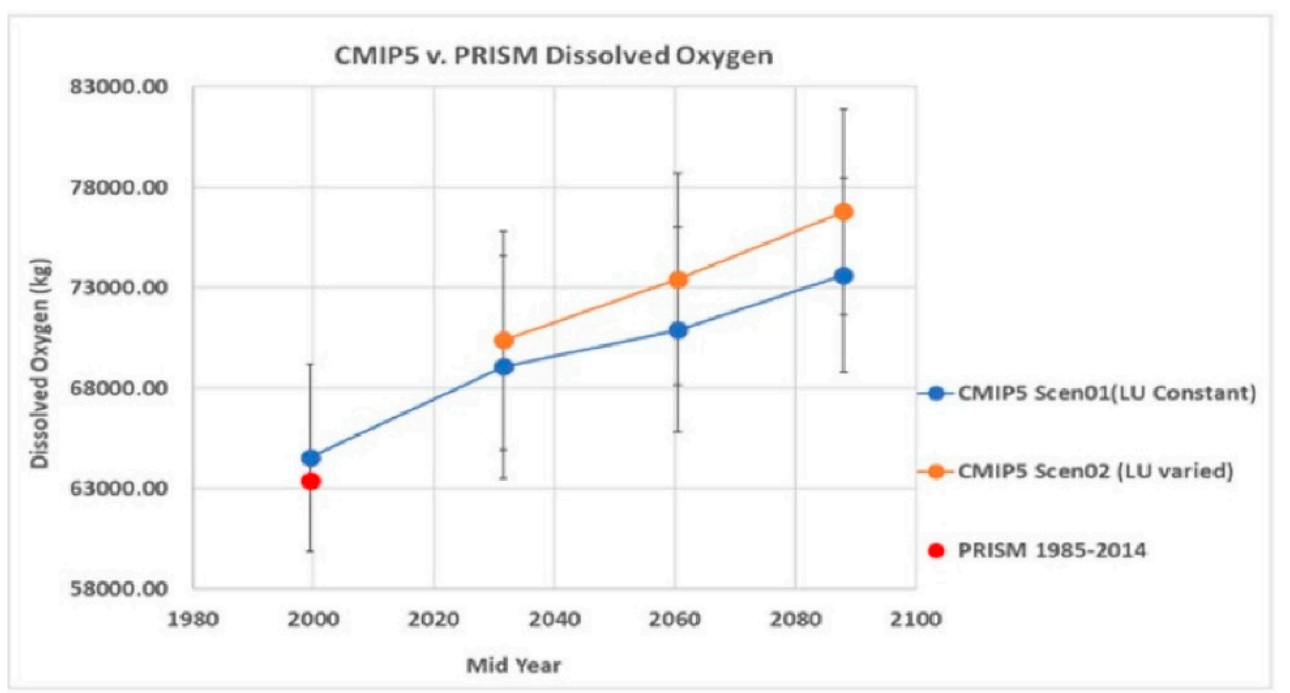

Figure 11. PRISM vs. average of 20 CMIP5 GCMs dissolved oxygen (2018-2100). 


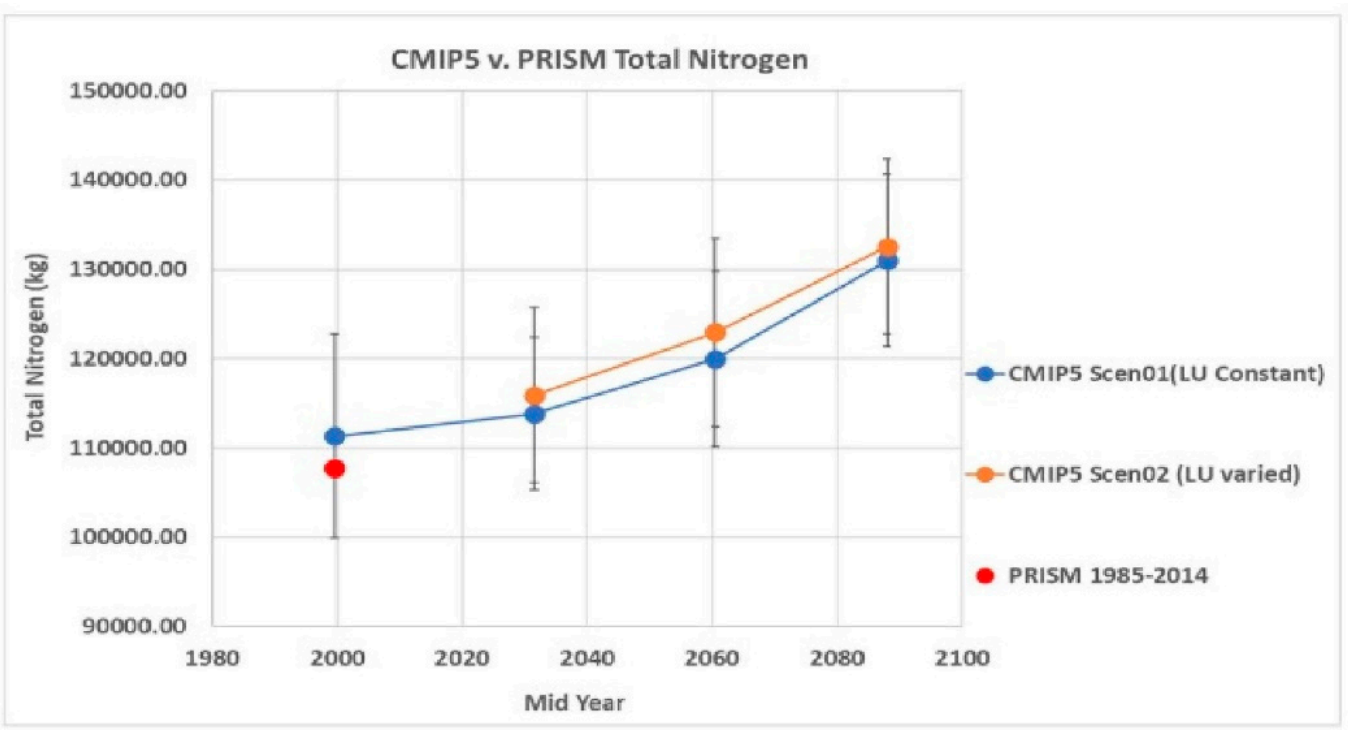

Figure 12. PRISM vs. average of 20 CMIP5 GCMs total nitrogen (2018-2100).

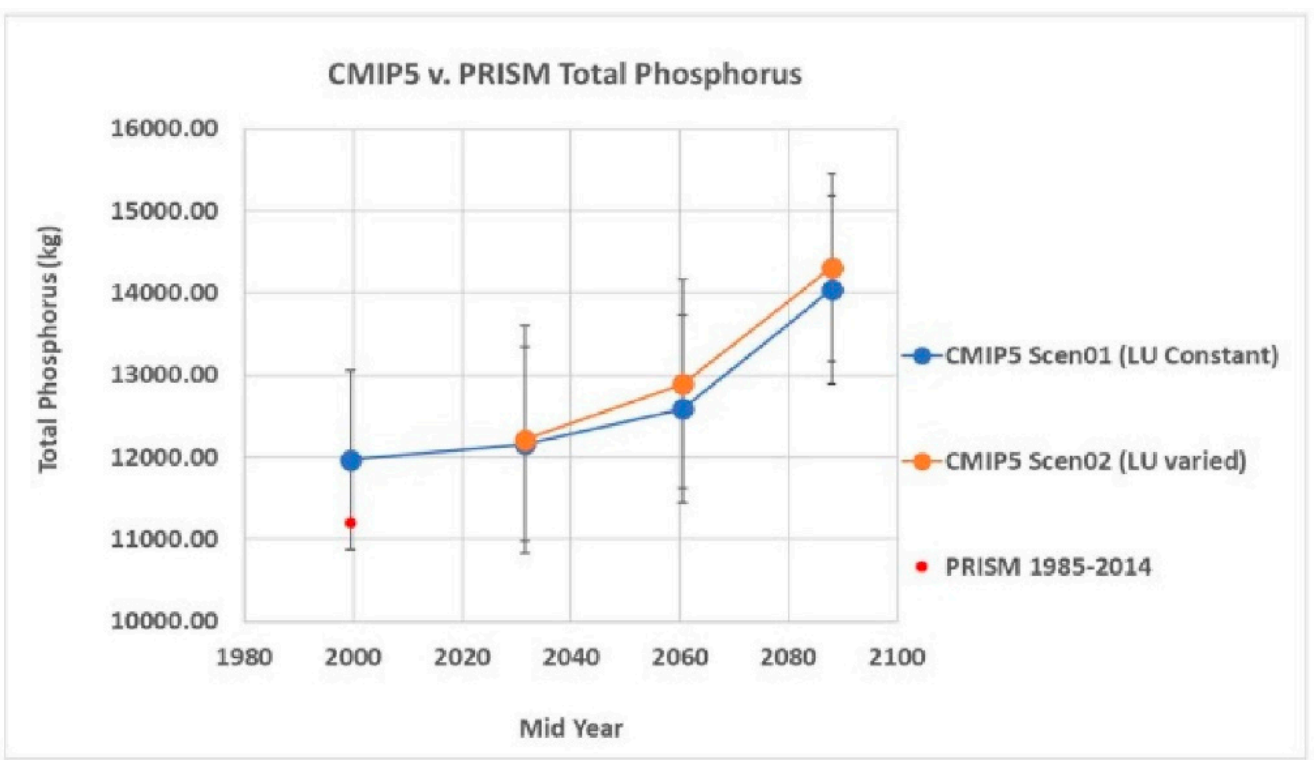

Figure 13. PRISM vs. average of 20 CMIP5 GCMs total phosphorus (2018-2100).

\subsection{Relationship between Variables}

Cross plots were made between flow and water quality variables (Figures 14-17). Flow is highly correlated with sediment across all the climate windows with $\mathrm{R}^{2}$ value of 0.99 . This shows that flow controls the sediment and that explains the similar trend between flow and sediment across the climate windows. Flow also correlated well with total nitrogen, total phosphorus, and organic phosphorus with strong $R^{2}$ values of 0.95 , 0.90 , and 0.92 , respectively, but shows no correlation with mineral phosphorus. Apparently, the projected increase in flow is expected to lead to an increase in water quality variables that are positively correlated with flow across the climate windows. 
Table 6. Percentage change in the simulated variables relative to the historical climate window across the century.

\begin{tabular}{|c|c|c|c|c|c|c|}
\hline Dataset & Mid-Year & Flow (\%) & Sediment (\%) & $\begin{array}{c}\text { Organic } \\
\text { Nitrogen }(\%)\end{array}$ & $\begin{array}{c}\text { Organic } \\
\text { Phosphorus } \\
(\%)\end{array}$ & $\begin{array}{c}\text { Mineral } \\
\text { Phosphorus } \\
(\%)\end{array}$ \\
\hline $\begin{array}{c}20 \text { CMIP5 } \\
\text { GCMs } \\
\text { 1985-2014 } \\
20 \text { CMIP5 }\end{array}$ & 1999.50 & - & - & - & - & - \\
\hline $\begin{array}{c}\text { GCMs Scenario } \\
\text { 1_2018-45 } \\
20 \text { CMIP5 }\end{array}$ & 2031.50 & 7.59 & 9.79 & 3.88 & 2.14 & -1.02 \\
\hline $\begin{array}{c}\text { GCMs Scenario } \\
2 \_2018-45 \\
20 \text { CMIP5 }\end{array}$ & 2031.50 & 9.69 & 11.51 & 4.94 & 4.79 & -11.68 \\
\hline $\begin{array}{c}\text { GCMs Scenario } \\
\text { 1_2046-75 } \\
20 \text { CMIP5 }\end{array}$ & 2060.50 & 13.64 & 20.55 & 8.02 & 6.94 & -3.47 \\
\hline $\begin{array}{c}\text { GCMs Scenario } \\
2 \_2046-75 \\
20 \text { CMIP5 }\end{array}$ & 2060.50 & 18.28 & 24.85 & 9.56 & 11.62 & -11.63 \\
\hline $\begin{array}{c}\text { GCMs Scenario } \\
1 \_2076-00 \\
20 \text { CMIP5 }\end{array}$ & 2088.00 & 23.76 & 36.66 & 17.93 & 19.96 & 4.45 \\
\hline $\begin{array}{c}\text { GCMs Scenario } \\
\text { 2_2076-00 }\end{array}$ & 2088.00 & 28.06 & 40.13 & 20.09 & 25.07 & -7.51 \\
\hline Dataset & Mid-Year & $\begin{array}{c}\text { Chlorophyll a } \\
(\%)\end{array}$ & CBOD (\%) & $\begin{array}{c}\text { Dissolved } \\
\text { Oxygen (\%) }\end{array}$ & $\begin{array}{c}\text { Total Nitrogen } \\
\text { (\%) }\end{array}$ & $\begin{array}{c}\text { Total } \\
\text { Phosphorus } \\
(\%)\end{array}$ \\
\hline $\begin{array}{c}20 \text { CMIP5 } \\
\text { GCMs } \\
1985-2014 \\
20 \text { CMIP5 }\end{array}$ & 1999.50 & - & - & - & - & - \\
\hline $\begin{array}{c}\text { GCMs Scenario } \\
1 \_2018-45 \\
20 \text { CMIP5 }\end{array}$ & 2031.50 & 6.40 & 10.99 & 6.98 & 2.25 & 1.60 \\
\hline $\begin{array}{c}\text { GCMs Scenario } \\
2 \_2018-45 \\
20 \text { CMIP5 }\end{array}$ & 2031.50 & 7.99 & 12.48 & 9.04 & 4.11 & 2.01 \\
\hline $\begin{array}{c}\text { GCMs Scenario } \\
1 \_2046-75 \\
20 \text { CMIP5 }\end{array}$ & 2060.50 & 9.41 & 20.41 & 9.84 & 7.74 & 5.18 \\
\hline $\begin{array}{c}\text { GCMs Scenario } \\
2 \_2046-75 \\
20 \text { CMIP5 }\end{array}$ & 2060.50 & 12.01 & 22.71 & 13.76 & 10.42 & 7.70 \\
\hline $\begin{array}{c}\text { GCMs Scenario } \\
\text { 1_2076-00 } \\
20 \text { CMIP5 }\end{array}$ & 2088.00 & 22.10 & 39.58 & 14.06 & 17.67 & 17.34 \\
\hline $\begin{array}{c}\text { GCMs Scenario } \\
2 \_2076-00\end{array}$ & 2088.00 & 22.97 & 43.34 & 18.96 & 19.08 & 19.57 \\
\hline
\end{tabular}




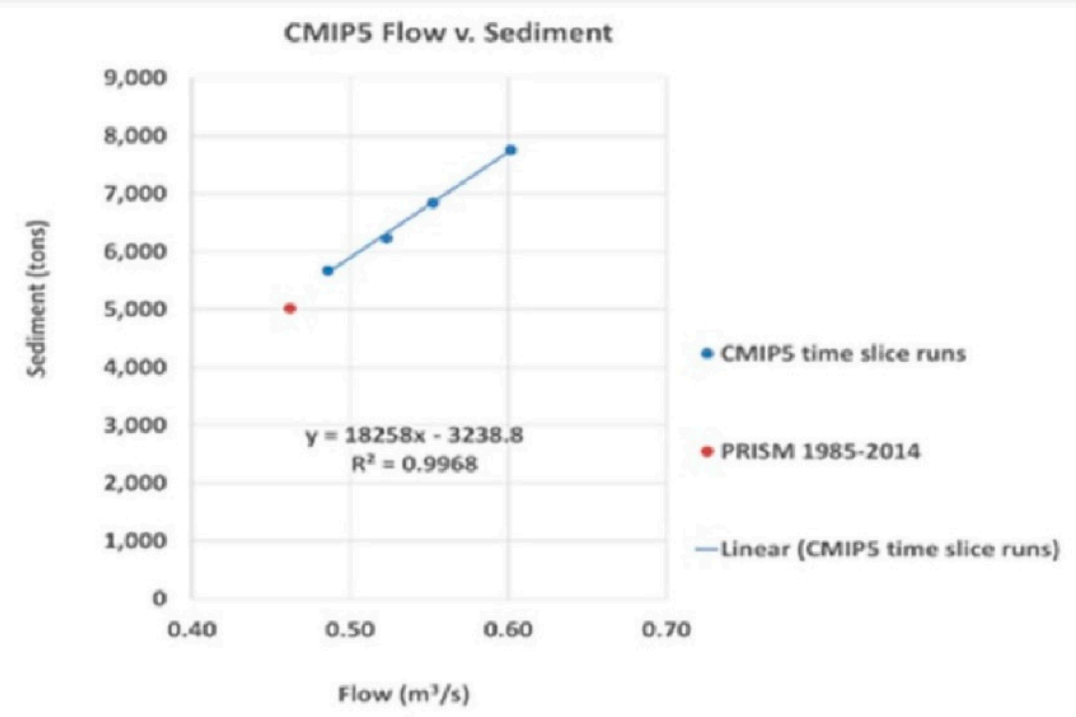

Figure 14. Average of 20 CMIP5 GCMs flow vs. sediment (2018-2100).

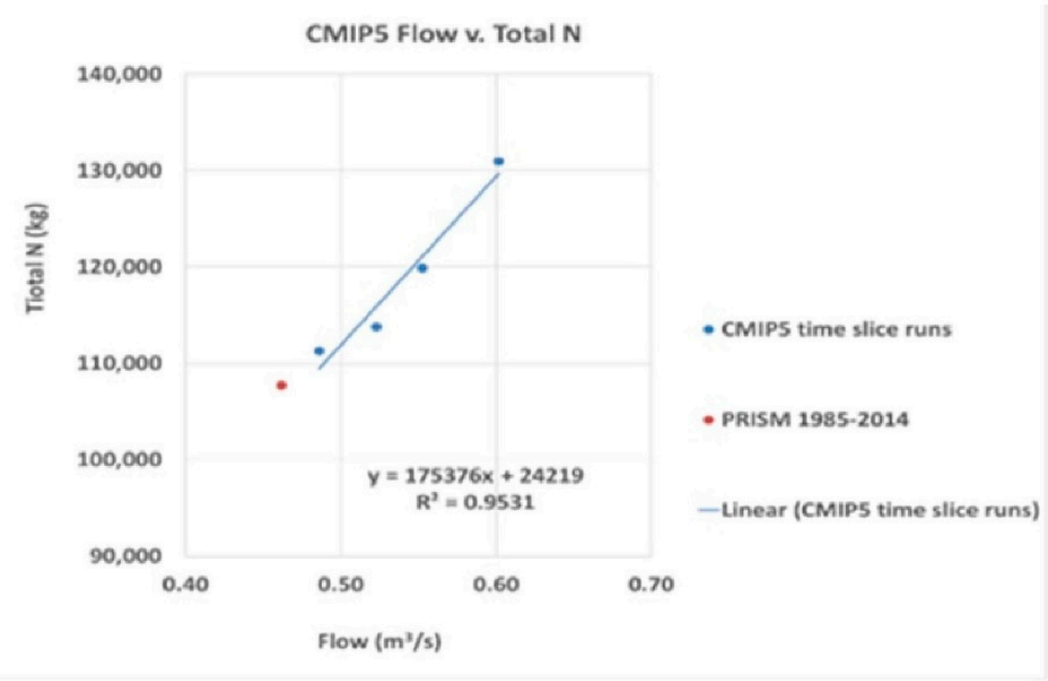

Figure 15. Average of 20 CMIP5 GCMs flow vs. total nitrogen (2018-2100).

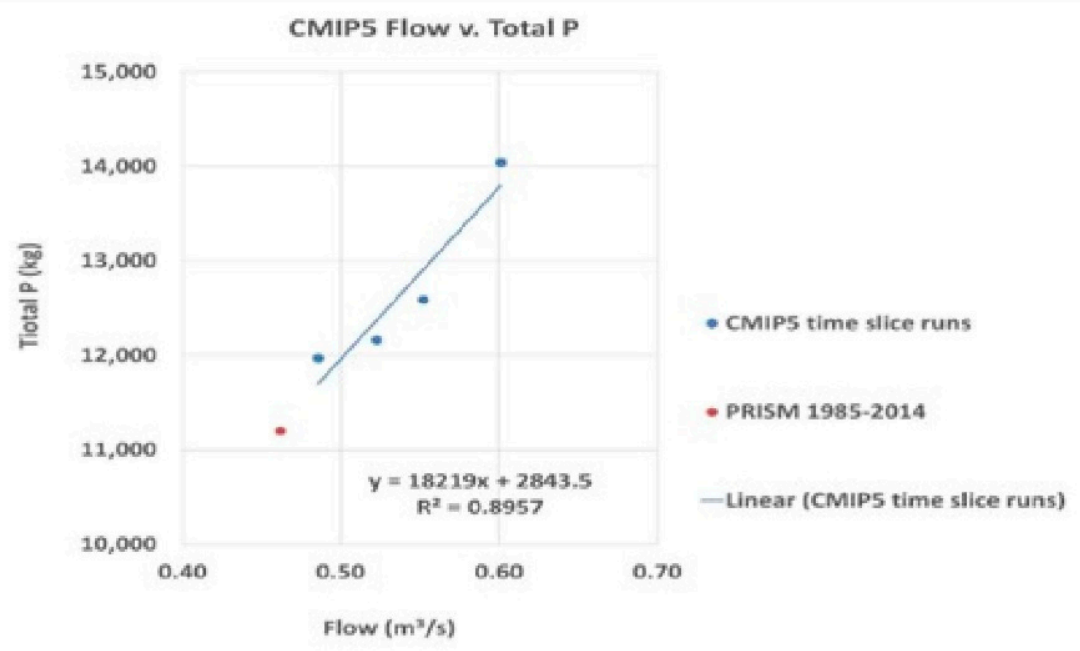

Figure 16. Average of 20 CMIP5 GCMs flow vs. total phosphorus (2018-2100). 


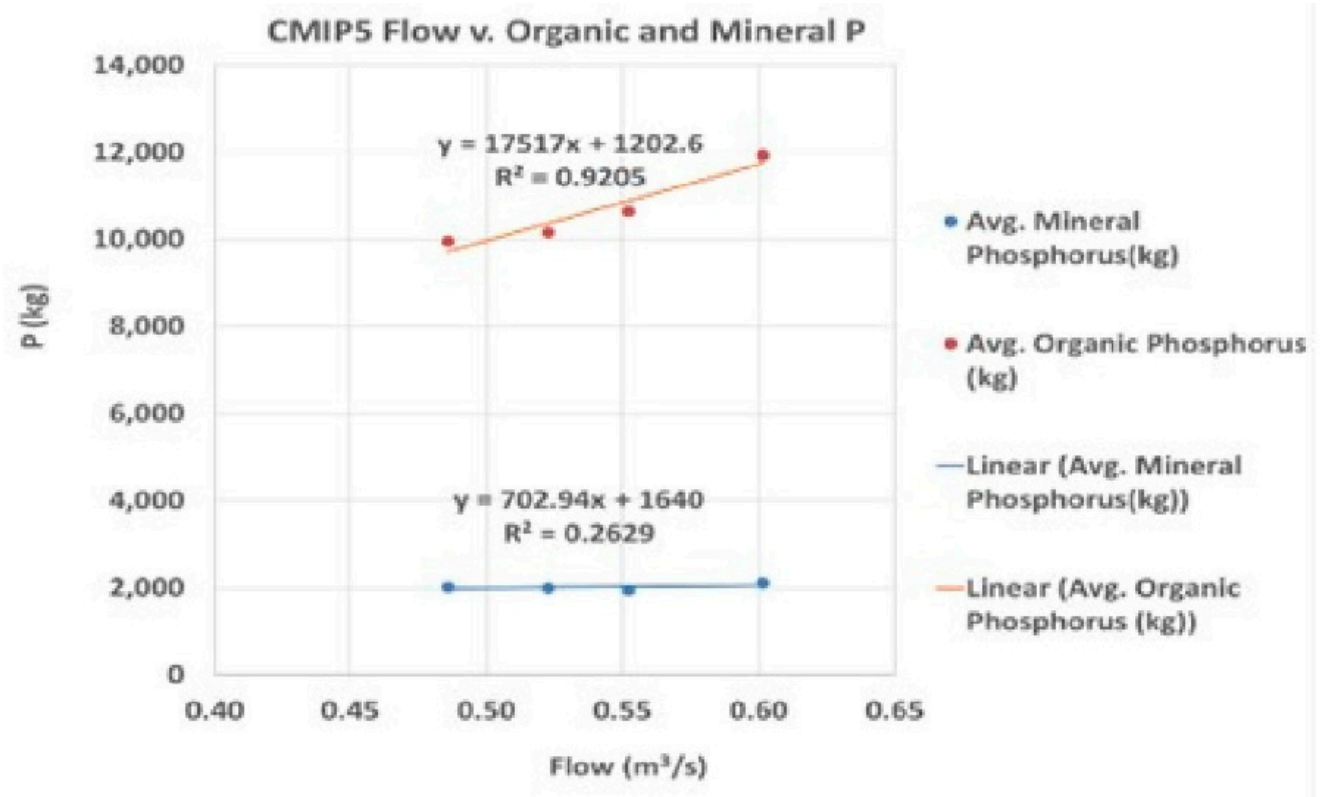

Figure 17. Average of 20 CMIP5 GCMs flow vs. organic and mineral phosphorus (2018-2100).

\section{Discussion}

For the historical climate window, the average of the 20 CMIP5 GCMs' results is a better predictor of the PRISM results than the individual results of the 20 GCMs model, and hence, the $20 \mathrm{GCMs}$ can be used to run simulations for the future climate windows.

For Scenarios 1 and 2's inter-model variability result, the effect of the projected climate change, which is $(+13 \%)$ in precipitation and temperature $(+47 \%)$, is seen in Scenario 1. The slight increase in streamflow and water quality variables in Scenario 2 relative to Scenario 1 is attributed to the effect of $(+0.58 \%)$ in urbanization seen in Scenario 2, which increases surface runoff. A decrease in agricultural land makes less land available for infiltration, which increases flow. The synergistic effect of a $0.8 \%$ decrease in agricultural land and $0.58 \%$ increase in urbanization in Scenario 2 would, therefore, increase flow and sediment transport.

The effect of the slight increase in urbanization and slight decrease in agriculture in Scenario 2 compared to 1 appears to be more in nutrient transport than in flow and sediment transport.

The reduction in mineral phosphorus (SRP) in Scenario 2 relative to Scenario 1 is attributed to the dissolution and the addition of the mineral phosphorus to the total phosphorus. This was evident by the associated reduction in crop yield across the climate windows. Hence, more mineral phosphorus is being dissolved, thereby increasing the concentration of total phosphorus in the estuary. The increase in other nutrients would drive more eutrophication leading to anoxic condition within the estuary.

For Scenarios 1 and 2's inter-annual variability result, the increase in flow drives sediment and nutrients transport. The projected high increase in CBOD and sediment transport will deteriorate the water quality, high total suspended sediment would affect water clarity, and high CBOD content would affect the dissolved oxygen content. As for mineral phosphorus, the effect of the projected change in agricultural land use in Scenario $2(-3.6 \%$ in agriculture) created a decrease in the quantity of the mineral phosphorus transported relative to Scenario 1. The reduction in mineral phosphorus (SRP) is attributed to the dissolution and addition of mineral phosphorus in the system to the total phosphorus content. Mineral phosphorus is the only water quality variable that decreased from Scenario 1 to Scenario 2. The effect of the projected changes in LULC results in a small impact relative to the effect of climate change. 
Similar results have been obtained by other researchers. Michalak et al. [26] carried out hydrological modeling of the Maumee River basin using SWAT and found an estimated increase in sediment and nutrient transport associated with the projected climate change. Du et al. [27] used SWAT modeling to evaluate the impact of LULC and climate change on runoff in the Dagu River basin in China and found out that the impact of LULC was lower than that of climate.

In this analysis, the most affected variables are streamflow, sediment transport, and CBOD. High stream flow would increase the vulnerability of the stream to flooding and would also increase sediment transport. High sediment transport would increase water turbidity and disrupt some aquatic habitats. High CBOD will lower the dissolved oxygen level in the water leading to the loss of aquatic lives. The results obtained from this work as shown by the cross plot are similar to those obtained by Stumpf et al. [28,29], who created models that forecast cyanobacteria bloom in Lake Erie using the Maumee River discharge and total phosphorus load.

The stochastic uncertainty of the model results for the OWC watershed is explained based on the previous analysis made by Evenson et al. [30]; they used five newly constructed watershed-scale models consisting of four SWAT models and one spatially referenced regression on watershed attributes (SPARROW) model, with different structure, input sources, and parameterization to assess the critical source areas (CSAs) uncertainty in the Maumee River watershed. Similar to the OWC watershed, the Maumee River watershed is a tributary of Lake Erie, primarily dominated by agricultural land use ( 70\%), which releases high phosphorus loads to the Lake Erie [31,32]. They observed a weak-tomoderate correlation in the sub watersheds of the five models, an agreement in the CSAs subset location, and a weak agreement in the CSAs location among five models. They attributed CSA uncertainty to the structural differences in the models and noted that the presence of uncertainty does not mean that the results of the simulations cannot be used for its intended purpose. All possible sources of model uncertainty should be evaluated using several models produced by different research organizations [30].

In this regard, the results of this analysis may be biased by model and climate uncertainties, which could be eliminated by comparing with similar results from other sources before use in decision making.

\section{Conclusions}

For the historical climate window results, the average of the 20 CMIP5 GCMs' results for all the 10 variables of interest are more consistent with the PRISM results than each of the 20 individual GCMs' results, and thus, the average is a better predictor of the PRISM results within acceptable error of SWAT simulation. The variability is smaller in the average of the 20 GCMs' results being the average of 20 different results compared to the PRISM result, which is one.

For the current-to-future climate window, the results of Scenario 1 represent the effect of the projected climate change only. In Scenario 2, the slight increase in urbanization would increase surface runoff, and the slight decrease in agriculture would make less land available for infiltration, thereby increasing flow. Although these changes are not statistically different given the uncertainty in the model estimates, the synergistic effect of increasing urbanization and decreasing agricultural land is observed as an increase in flow, sediment transport, organic nitrogen transport, organic phosphorus transport, total nitrogen, and total phosphorus. Decrease or loss of mineral phosphorus observed in Scenario 2 relative to Scenario 1 is attributed to the dissolution of mineral phosphorus.

The progressive increase observed in flow and eight water quality variables across the century shows that there would be greater eutrophication and anoxic condition, which would further deteriorate the water quality in OWC estuary as time goes on. The flow controls the sediment and nutrient transport. Higher flow and nutrient transport are predicted for the future climate windows. Comparison between Scenarios 1 and 2 shows 
that the projected LULC change in the 21st century has a smaller impact on the water quality of Old woman creek compared to climate change.

Finally, the synergistic effect of the projected climate and LULC change observed in Scenario 2 increases across the climate windows. Not all the increase observed in nutrients would settle in the OWC estuary; a proportion would be transported into Lake Erie. The increase would drive proportional increase in eutrophication in both the OWC estuary and Lake Erie, thereby further deteriorating the water quality in the OWC estuary and Lake Erie.

The results of this work would assist the Huron and Erie counties in making policies relating to the land use management within the OWC watershed. It would assist the Ohio Department of Natural Resources (ODNR) and the management of OWC (NERR) in policies that would foster better management of the OWC estuary. It would assist the Ohio coastal management agencies in water quality studies in Lake Erie. The result would also serve as a reference for water quality studies in watersheds with dominantly agricultural land use in the United States and across the world.

Author Contributions: Conceptualization, J.D.O., I.A.O., and R.B.C.J.; methodology and software, R.B.C.J. and I.A.O.; validation, I.A.O. and R.B.C.J.; formal analysis, visualization, and writingoriginal draft preparation, I.A.O.; project supervision, J.D.O. and R.B.C.J.; review and editing, J.D.O. and R.B.C.J. All authors have read and agreed to the published version of the manuscript.

Funding: This research received no external funding.

Institutional Review Board Statement: Not Applicable.

Informed Consent Statement: Not Applicable.

Acknowledgments: The authors wish to acknowledge Abdul Shakoor and Anne Jefferson of Kent State University, Ohio for their insightful comments and review of the Ph.D. dissertation from where this manuscript was extracted. They also wish to acknowledge the support received from the Old Woman Creek National Estuarine Research Reserve, Ohio, USA for data accessibility, the National Water Quality Laboratory at Heidelberg University, Ohio, USA for access to their Beowulf cluster of computers, the department of Geology Kent State University, Ohio, USA, and the Texas Institute for Applied Environmental Research (TIAER), Tarleton State University, Member of the Texas A\&M System, Stephenville, Texas, USA.

Conflicts of Interest: The authors declare no conflict of interest.

\section{Appendix A}
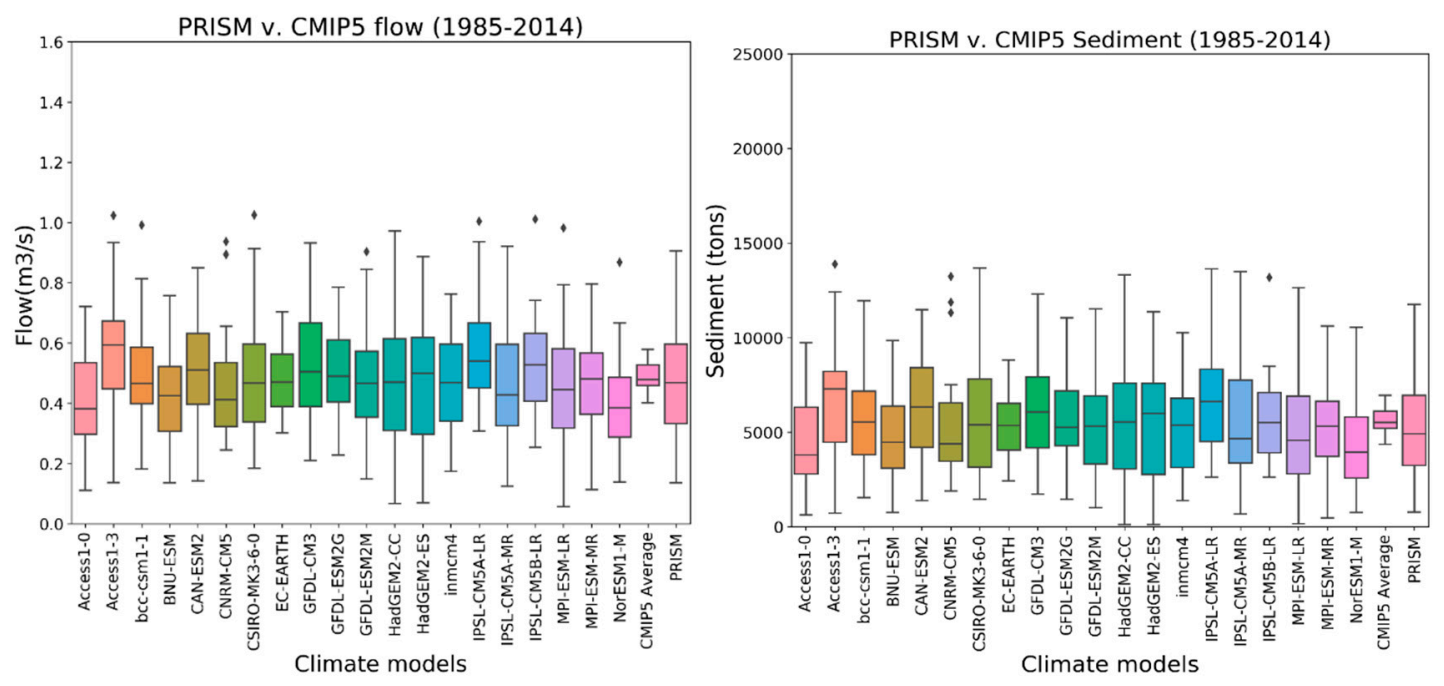

Figure A1. Cont. 

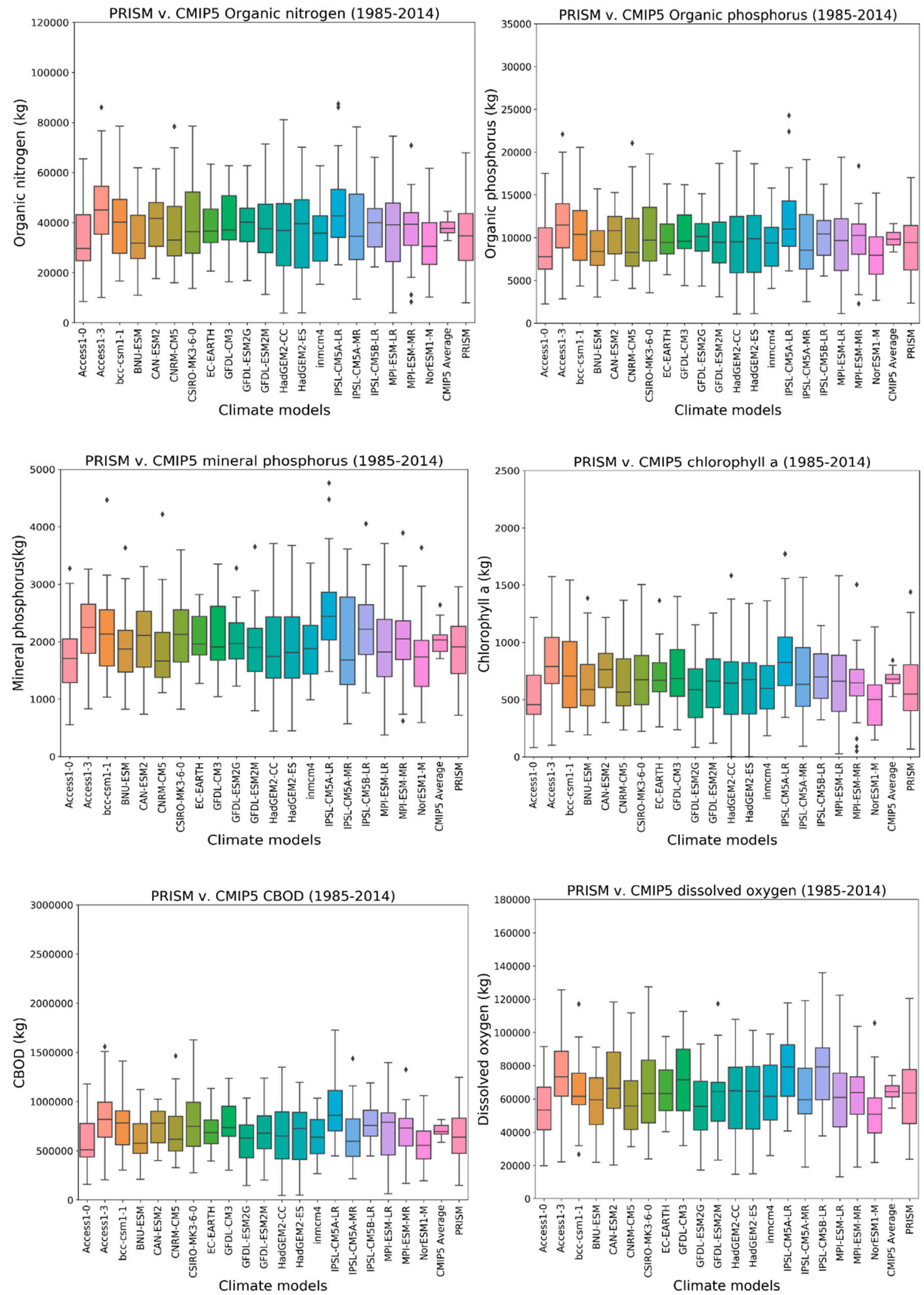

Figure A1. Cont. 

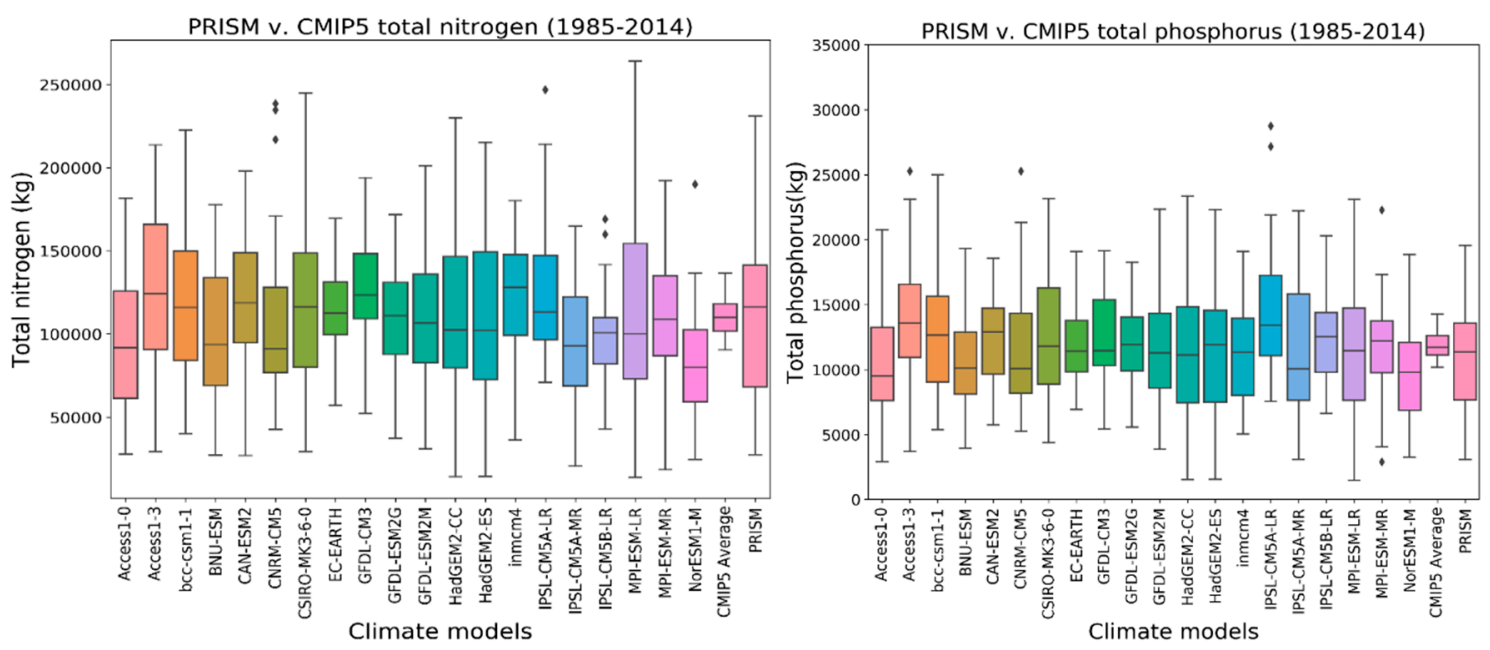

Figure A1. PRISM and the 20 CMIP5 GCMs simulations result for flow and water quality variables (dots represent the outliers).

\section{References}

1. Scanlon, B.R.; Reedy, R.C.; Stonestrom, D.A.; Prudic, D.E.; Dennehy, K.F. Impact of land use and land cover change on groundwater recharge and quality in the southwestern US. Glob. Chang. Biol. 2005, 11, 1577-1593. [CrossRef]

2. Schilling, K.E.; Jha, M.K.; Zhang, Y.-K.; Gassman, P.W.; Wolter, C.F. Impact of land use and land cover change on the water balance of a large agricultural watershed: Historical effects and future directions. Water Resour. Res. 2008, 44. [CrossRef]

3. Fu, B.J.; Chen, L.D.; Ma, K.M.; Zhou, H.F.; Wang, J. The relationships between land use and soil condi-tions in the hilly area of the loess plateau in northern Shaanxi, China. Catena 2000, 39, 69-78. [CrossRef]

4. Getachew, H.; Melesse, A. The impact of land use change on the hydrology of the Angereb watershed, Ethiopia. Int. J. Water Sci. 2012, 1, 1-7.

5. Gwate, O.; Woyessa, Y.; Wiberg, D. Dynamics of land cover and impact on streamflow in the Modder River Basin of South Africa: Case study of a Quaternary catchment. Int. J. Environ. Prot. Pol. 2015, 3, 31-38.

6. Gebremicael, T.; Mohamed, Y.; Betrie, G.; van der Zaag, P.; Teferi, E. Trend analysis of runoff and sediment fluxes in the Upper Blue Nile basin: A combined analysis of statistical tests, physically-based models and landuse maps. J. Hydrol. 2013, 482, 57-68. [CrossRef]

7. Radeloff, V.C.; Hammer, R.B.; Stewart, S.I. Rural and Suburban Sprawl in the U.S. Midwest from 1940 to 2000 and Its Relation to Forest Fragmentation. Conserv. Biol. 2005, 19, 793-805. [CrossRef]

8. Mishra, V.; Cherkauer, K.A.; Niyogi, D.; Lei, M.; Pijanowski, B.C.; Ray, D.K.; Bowling, L.C.; Yang, G. A regional scale assessment of land use/land cover and climatic changes on water and energy cycle in the upper Midwest United States. Int. J. Clim. 2010, 30, 2025-2044. [CrossRef]

9. Niyogi, D.; Holt, T.; Zhong, S.; Pyle, P.C.; Basara, J. Urban and land surface effects on the 30 July 2003 mesoscale convective system event observed in the southern Great Plains. J. Geophys. Res. Space Phys. 2006, 111. [CrossRef]

10. Alberti, L.; Cantone, M.; Colombo, L.; Oberto, G.; La Licata, I. Assessment of aquifers groundwater storage for the mitigation of climate change effects. Rend. Online Della Soc. Geol. Ital. 2016, 39, 89-92. [CrossRef]

11. Oberto, G.; Alberti, L.; Sessa, R.S.; Colombo, L. Coupled irrigation-system/groundwater flow modelling for groundwater resource assessment in agricultural areas: A case study in northern Italy. Rend. Online Della Soc. Geol. Ital. 2018, 46, 94-100. [CrossRef]

12. Bhattarai, G.; Hite, D.; Hatch, U. Estimating the Impact on Water Quality under Alternate Land Use Scenarios: A Watershed Level BASINS-SWAT Modeling in West Georgia, United States. In Efficient Decision Support Systems-Practice and Challenges in Multidisciplinary Domains; Jao, C.S., Ed.; InTech: Rijeka, Croatia, 2011.

13. Fall, S.; Niyogi, D.; Gluhovsky, A.; Pielke, R.A.; Kalnay, E.; Rochon, G. Impacts of land use land cover on temperature trends over the continental United States: Assessment using the North American Regional Reanalysis. Int. J. Clim. 2009, 30, 1980-1993. [CrossRef]

14. Bewket, W. Land Cover Dynamics Since the 1950s in Chemoga Watershed, Blue Nile Basin, Ethiopia. Mt. Res. Dev. 2002, 22, 263-269. [CrossRef]

15. Lambin, E.; Geist, H.; Lepers, E. Dynamics of land use and land cover change in tropical regions. Annu. Rev. Environ. Resour. 2003, 28, 206-232. [CrossRef]

16. Herdendorf, C.E.; Klarer, D.M.; Herdendorf, R.C. The Ecology of Old Woman Creek, Ohio: An Es-Tuarine and Watershed Profile, 2nd ed.; Ohio Department of Natural Resources, Division of Wildlife: Columbus, OH, USA, 2006.

17. Olaoye, I.; Confesor, R.; Ortiz, J. Impact of Seasonal Variation in Climate on Water Quality of Old Woman Creek Watershed Ohio Using SWAT. Climate 2021, 9, 50. [CrossRef] 
18. Yang, W.; Andréasson, J.; Graham, L.P.; Olsson, J.; Rosberg, J.; Wetterhall, F. Distribution-based scaling to improve usability of regional climate model projections for hydrological climate change impacts studies. Hydrol. Res. 2010, 41, 211-229. [CrossRef]

19. Neitsch, S.L.; Arnold, J.G.; Kiniry, J.R.; Srinivasan, R.; Williams, J.R. Soil and Water Assessment Tool User's Manual Version 2000; TWRI Report TR-192; Texas Water Resources Institute: College Station, TX, USA, 2000; Volume 202.

20. Arnold, J.G.; Srinivasan, R.; Muttiah, R.S.; Williams, J.R. Large area hy-drologic modeling and as-sessment-Part 1: Model development. J. Am. Water Resour. Assoc. 1998, 34, 73-89. [CrossRef]

21. Gull, S.; Ma, A.; Dar, A.M. Prediction of Stream Flow and Sediment Yield of Lolab Watershed Using SWAT Model. J. Waste Water Treat. Anal. 2017, 8, 265. [CrossRef]

22. Di Luzio, M.; Srinivasan, R.; Arnold, J.G.; Neitsch, S.L. ArcView Interface for SWAT2000: User's Guide; TWRI Report TR-193; Texas Water Resources Institute: Forney, TX, USA, 2002.

23. Confesor, R.B., Jr.; Whittaker, G.W. Automatic Calibration of Hydrologic Models with Multi-Objective Evolutionary Algorithm and Pareto Optimization. JAWRA J. Am. Water Resour. Assoc. 2007, 43, 981-989. [CrossRef]

24. R-Development-Core-Team. R: A Language and Environment for Statistical Computing; R Foundation for Statistical Computing: Vienna, Austria, 2011; Available online: http:/ / www.r-project.org (accessed on 31 January 2019).

25. Nash, J.E.; Suttcliffe, J.E. River Flow Forecasting Through Conceptual Models—Part I: A Discussion of Principles. J. Hydrol. 1970, 10, 282-290. [CrossRef]

26. Michalak, A.M.; Anderson, E.J.; Beletsky, D.; Boland, S.; Bosch, N.S.; Bridgeman, T.B.; Chaffin, J.D.; Cho, K.; Confesor, R.; Daloglu, I.; et al. Record-setting algal bloom in Lake Erie caused by agricultural and meteorologi-cal trends consistent with expected future conditions. Proc. Natl. Acad. Sci. USA 2013, 110, 6448-6452. [CrossRef] [PubMed]

27. Du, F.-H.; Tao, L.; Chen, X.-M.; Yao, H.-X. Runoff Simulation Using SWAT Model in the Middle Reaches of the Dagu River Basin. In Sustainable Development of Water Resources and Hydraulic Engineering in China; Dong, W., Lian, Y., Zhang, Y., Eds.; Springer: Cham, Switzerland, 2019.

28. Stumpf, R.P.; Wynne, T.T.; Baker, D.B.; Fahnenstiel, G.L. Interannual Variability of Cyanobacterial Blooms in Lake Erie. PLoS ONE 2012, 7, e42444. [CrossRef]

29. Stumpf, R.P.; Johnson, L.T.; Wynne, T.T.; Baker, D.B. Forecasting annual cyanobacterial bloom bio-mass to inform management decisions in Lake Erie. J. Great Lakes Res. 2016, 42, 1174-1183. [CrossRef]

30. Evenson, G.R.; Kalcic, M.; Wang, Y.-C.; Robertson, D.; Scavia, D.; Martin, J.; Aloysius, N.; Apostel, A.; Boles, C.; Brooker, M.; et al. Uncertainty in critical source area predictions from watershed-scale hydrologic models. J. Environ. Manag. 2021, 279, 111506. [CrossRef]

31. Manning, N.F.; Wang, Y.-C.; Long, C.M.; Bertani, I.; Sayers, M.J.; Bosse, K.R.; Shuchman, R.A.; Scavia, D. Extending the forecast model: Predicting Western Lake Erie harmful algal blooms at multiple spatial scales. J. Great Lakes Res. 2019, 45, 587-595. [CrossRef]

32. Baker, D.; Confesor, R.; Ewing, D.; Johnson, L.; Kramer, J.; Merryfield, B. Phosphorus loading to Lake Erie from the Maumee, Sandusky and Cuyahoga rivers: The importance of bioavailability. J. Great Lakes Res. 2014, 40, 502-517. [CrossRef] 